\title{
FİLİSTİN CEPHESİ TÜRK HAVA HAREKÂTI
}

\section{Osman YALÇIN*}

\section{$\ddot{\mathbf{O}} \mathbf{z}$}

Osmanlı İmparatorluğu'nun son yıllarında dünyada meydana gelen ve askerî alanda önemli bir değişime neden olacak olan gelişmelerin ilklerinden biri, havacılıktır. Osmanlı bir taraftan birliğini korumak için isyanlar ve Osmanlı üzerinde emelleri bulunan devletlerin emellerine engel olmaya çalışırken diğer taraftan ayakta kalabilmek için teknik alandaki gelişmelere odaklanmıştır. Trablusgarp ve Balkan Savaşları ile önemli darbe alan Osmanlı Devleti, ordunun modernizasyonu için yapılanmaya girişmiştir. Yeterli zaman bulamadan Birinci Dünya Savaşı'na girmek durumunda kalması önemli bir kayıp olmuştur.

Osmanlı İmparatorluğu büyük savaşta yaklaşı 5 milyon kilometre karelik alanda birçok cephede savaşmak zorunda kalmıştır. Bu cephelerden birisi de Filistin Cephesi olmuştur. "Kanal Cephesi" olarak açılmış ve zamanla "Sina - Filistin" ve "Suriye - Filistin" adlarını almıştır. Cephe için Cemal Paşa kumandasındaki 4'üncü Ordu Kumandanlığı görevlendirilmiştir. Kanal Harekâtı ve Gazze Savaşları önemli mücadelelerdendir. Savaş süresince cephede birçok tayyare bölüğü görev almıştır. Bu bölükler; 3, 4 ve 14'üncü Tayyare Bölükleri ile Alman Paşa Bölükleri olarak tanımlanan 6 tayyare bölüğünden oluşmaktadır.

Filistin Cephesi günümüze bakan yönü ile de hâlen diridir ve incelenmesi hâlinde önemli dersler alınacak hususlara haizdir. Teknolojik olarak ileride olan ve eğitimli bir ordunun nasıl başarılı olacağını her iki tarafın faaliyetinde görmek mümkündür. Filistin Cephesi; Türk hava unsurunun tarihine büyük başarıları kaydettiği ve bu kapsamda 104 düşman uçağını düşürdüğü, savaşın son y1lına kadar hava hâkimiyetini büyük oranda elinde tuttuğu bir cephedir. Filistin Cephesi; iktisadi hayat ve sanayi alanında gelişimini tamamlayamayan ve hava endüstrisini kuramayan Osmanlı İmparatorluğunun, kahraman ordusunun hazin çöküşünün de yaşandığı yerdir.

Anahtar Sözcükler: Filistin Cephesi, Paşa Bölüğü, Osmanlı Ordusu, Türk havacılar, Kanal Harekâtı, Gazze Savaşları

\section{TURKISH AIR EXPEDITION IN PALESTINE FRONT}

\begin{abstract}
Aviation is one of the first of the developments in the world which would cause a dramatic change in military service in the last years of Ottoman Empire. The Ottoman, focused on the technical developments to survive while trying to protect its unity and send away the aims of countries which were coveting its lands. Taking a big hit from the Balkan and Tripoli Battles, Ottoman Army initiated a reconstruction for the modernization of the troops. It was a huge deficiency that The Ottoman had to go to World War I without having enough time for these modernization endeavors.
\end{abstract}

\footnotetext{
*Yrd. Doç. Dr.; Hava Harp Okulu Sosyal Bilimler Ana Bilim Dalı, kusegen8935@ gmail.com.
} 
Ottoman Empire had to fight in this big war in a 5 million $\mathrm{km}^{2}$ square field in lots of fronts. Palestine front is one of those fronts. It was opened as "Channel Front" and was called as "Sina-Palestine" and "Syria-Palestine". 4th Army Commander was assigned under the command of Cemal Pasha for the front. Channel expedition and Gazze Battle were the most important struggles. During war, lots of aircraft troops were assigned. These troops are; 3rd, 4th and $14^{\text {th }}$ aircraft troops and $6^{\text {th }}$ plane troop described as German Pasha Troop.

Palestine front is still alive from today's perspective and consists of important things to be learned when investigated. It is possible to see how successful a trained and technologically advanced army can be is seen in actions of both sides. Palestine is a front in which Turkish air units recorded great victories in its history and on basis of this; they hit 104 enemy aircrafts and held the air supremacy until the last year of the war. Palestine front, at the same time, is a place where heroic army of Ottoman Empire which could not complete its financial and industrial development and establish air industry was defeated in deep grief.

Keywords: Palestine Front, Pasha Troop, Ottoman Army, Turkish aviator, Channel Expedition, Gazze Battles.

\subsection{Giriş:}

Bu çalışmada Birinci Dünya Savaşı'nın önemli, Osmanlı İmparatorluğu açısından ise hayati öneme haiz Filistin Cephesi hava harekâtı ağırlıklı olarak incelenmiştir. Birinci Dünya Savaşı'nda diğer cepheler de şüphesiz oldukça önemlidir. Ancak Filistin Cephesi bir bakıma bir devrin bir süreliğine kapandığı yerdir. Adı yalnızca Filistin Cephesi olarak anılsa da; "Kanal Cephesi" olarak açılmış ve zamanla "Sina - Filistin" ve "Suriye - Filistin" adlarını almıştır. Bu nedenle burada yaşananların bir makale konusu olarak ele alınıp önemli görülen yönleri ile incelenmesinin konuyla ilgilenenlere katkı sağlayacağı değerlendirilmektedir.

Savaş için şartlar 19'uncu yüzyılın ikinci yarısının ortalarında başlar ve 20. Yüzyılın başında süratle bir çatışma ortamının zemininin güçlenmesi ile gelişir. Birliğini 1864, 1866 ve 1871 savaşları ile oldukça geç bir zamanda tamamlayan Almanya'nın dünyada güçlü bir konuma gelebilmek için imtiyazlar alıp ekonomisini geliştireceği alan arayışı dengeleri bozar. Şüphesiz 1885 Berlin Senedi ile sömürgecilik hızla gelişmeye başlamıştır. Alman subaylar Osmanlı İmparatorluğu'nun diğer sömürgeler gibi değerlendirilemeyeceğinin farkındadır. Zira Türkler hâlen en ufak bir firsatta cihangirlik iddiası ile ortaya çıkabilecek kadar aktiftirler. O hâlde Osmanlı ülkesinde etkili olmanın yolu ancak diplomasi ile mümkündür.

Osmanlı bu güçler dengesi arasındaki rekabetten de yaralanarak varlığını sürdürmektedir. Kayzer II. Wilhelm'in 300 milyon Müslüman'ın koruyuculuğuna yeltenmesi ve Berlin - Bağdat - Basra Demiryolu hattı ile Osmanlı - Alman işbirliği diğer dengeleri de 
yeniden şekillendirir. Birinci Dünya Savaşı'nın bir paylaşım olduğunu ve Osmanlı İmparatorluğu'nu da bu anafora çekeceğini devletin idarecileri bilmektedir. Bu nedenle Osmanlı diplomasisinin İngiltere, Fransa ve Rusya ile ittifak yapma girişimleri bir netice vermemiştir (Tuncay, 1990, s. 41). Mustafa Kemal de savaştan kaçınılmasının imkânsızlığını belirtir. Ancak giriş zamanlaması doğru muydu? (Çavdar, 2004, s. 152) Mustafa Kemal, savaş çıktığında Sofya'da askeri ataşedir. Savaştan mümkün olduğunca kaçınılması ve geciktirilmesi yönünde gayretleri olur. Ancak karar vericiler üzerinde etkili olamaz. Bugün Amerika'nın güç olma stratejisinde dünya savaşlarına geç girmesinin etkileri dikkate alındığında (Yalçın, 2013, 3 / 3, s. 15 - 17) bu konu üzerinde düşünülmesi gerektiği anlaşılmaktadır. Osmanlı orduları Amerikan ordusu ile direk savaşmasa da uygulanan politikadan Türk İmparatorluğu doğrudan etkilenmiştir. İngilizlerle birlikte İsrail'in kurulmasına inanan ve Balfour Deklarasyonu'na güç katan Amerikan Başkanı Wilson'un savaş sürecinde Türklere yönelik olumsuz tavrı da sonuçları itibariyle yıkıcı olmuştur. Amerika'nın ve İngiltere'nin Araplara büyük bir krallık vaadinde samimi olmadıklarının ilk emaresi Filistin'de Musevilere de bir yurt vaatleri olmuştur (Tunçay Akşin, 1990, s. 49; Palmer, s. 377).

Filistin'in öncelikle uluslararası bir statüde olması kararlaştırılırken, sonradan İngiliz mandası olmasına karar verilmiştir (Tolon, 2004, s. 143). Filistin üzerinde pazarlık ve hesaplar büyük harpten oldukça eski tarihlere dayanmaktadır. Sultan II. Abdülhamit döneminde iddia edilen borçların ödenmesi karşı1ığında Yahudi göçmenlere kolaylık sağlanması Osmanlı Arşivi kaynaklarına göre doğrudur (BOA, Y.MTV,285 / 162; Özdemir - Subaşı, 2009, s. 303).

Filistin Cephesi’nde yenilginin de en önemli sebepleri arasında dolaylı da olsa Amerika Birleşik Devletleri'nin Batı Cephesinde savaşa girmesi etkili olmuştur. İngilizlerin birliklerini Filistin ve Irak'a yığınak yaptırmaya başlaması ve 90.000 askerini göndermesi belirleyici olmuştur. Dönemin yazışmalarına bakıldığında 1880'lerden itibaren toprak satışının durdurulması, kontrol altında tutulması, Yahudi yayılmacılığına karşı askerî ve idari tedbirler alınması, Theodor Herzl'in faaliyetinin takibi konusunda ilgili birimlere İstanbul'dan farklı tarihlerde birçok yazışmalar yapılmıştır. Yerleşimleri sınırlayabilmek için bazı toprakların Padişah mülkü yapılması uygulaması da tatbik edilmiştir. Özellikle Siyonistlere vaat edilen Musevi devletin kurulmasına mani olmak için İngilizlerin Kudüs'e girmelerine müsaade edilmemesi istenmiştir. Amerikan Başkanı Wilson da Musevi Devleti için Rus Çarlığının desteğini istemiştir (BOA, Y.A.Res, 5 / 58; BOA, ŞD, TNZ, 2272 / 86; BOA, Y.PRK.EŞA, 13 / 67; BOA, İ.MMS, 123 / 5276; BOA, Y.PRK.UM, 23 / 66; BOA, Y.PRK.AZJ, 30 / 37; BOA, 
HR,SYS, 2160 / 3; BOA, HR.SYS.,2333 / 3; Özdemir-Subaş1, 2009, s. 231, 241, 25,285 / 162; $1-257,291,303,357,365,431)$.

Görüldüğü üzere Musevi Devleti projesi bir halkın mücadelesinin yanında dünyanın en güçlü ve gelişmiş ülkelerinin bir projesi olarak dayatılmıştır. Viyana'da toplanan İkinci Siyonist Kongresinden sonra Herzl'in, yazmış olduğu bir yazıda gayelerini açıklamış ve bu yazı Viyana'da çıkan Correspondance Devlet Gazetesi'nde 2, 3 Eylül 1898 tarihinde yayımlanmıştır. Herzl burada, Siyonistliği Musevilik olarak tanımlarken "Sen ver, ben de vereyim" kaidesinden hareketle Filistin'de yeniden yerleşmeye gayretlerini anlatmaktadır (Özdemir - Subaşı, 2009, s. 299 - 301; BOA, Y.PRK.TKM, 41 / 5). Bu amaca yönelik olarak Musevilerin ilk dönemlerde özellikle Theodor Herzl'in mektubu önemli bilgiler vermektedir. Musevi projesi Bale şehrinde toplanan iki kongrede bir plana alınmıştı. Oysa Herzl; “...Biz sizden teba’üd veya sizi terk edecek değiliz. İstikbalimizi istikbalinize rabt ve ta'lik arzusunda bulunuyoruz...." demekteydi. $\mathrm{Bu}$ belgede teklif edilen yalnız rüsum ve tekâlif ile istikrazı kapsamayacağı, devletin maliyesini toparlayacak bir düzenlemeyi kapsadığını belirtmekteydi. (BOA, Y.MTV, 285 / 162; Özdemir - Subaş1, 2009, s. 304). Bu mektubun 30 Nisan 1899 tarihinde Viyana'dan yazıldığı dikkate alındığı da Birinci Dünya Savaşı'na kadar olan sürede hedeflerin değiştiği ve Çanakkale'de bir tabur ile Osmanlı ordularının karşısına Yahudilerin de muharip bir güç olarak çıktığı anlaşılmaktadır.

Savaş başladığı zaman Batı Cephesinde yoğunluk oluşmuş ve Almanların planları Schlieffen Plânı (Şiflen Plânı) istedikleri gibi işlememiştir. "Almanların Marne'de durdurulması ve Fransa'nın mağlup edilememesi cephede büyük bir durgunluk yarattı ve İsviçre sınırından başlayıp Manş Denizi kıyılarına kadar uzanan karşılıklı siper sistemi ile çarpışmalar değişik bir şekil alarak 20'inci yüzyılın ilk büyük savaş gerçeği kendisini gösterdi (http://tanktarihi.tr.gg/Tank-Nedir.htm.E.Tarihi: 29. 08. 2015). Fransa'y1 belirtilen sürede saf dışı bırakamadıkları gibi Paris önlerinde Alman orduları duraklamak zorunda kalmıştır. Keza Rusya da beklenenden daha erken seferber olmayı başarmıştır. Bu bakımdan Almanlar için doğuda cepheler açılması ve düşmanların hedeflerinin artırılması gerekiyordu $\mathrm{Bu}$ şekilde Almanya kendi yükünü de azaltmış olacaktı (Miralay Muzaffer, 1934, s. 4).

Osmanlı İmparatorluğunun savaşa girmesi ile birçok cephede yoğun bir savaşın tarafı olmuştur. Bu cephelerden biri başlarda çok ön planda olmasa da zamanla Osmanlı orduları için savaşın en yoğun olduğu cepheye dönüşen Filistin Cephesi'dir. Şüphesiz bu dönemde savaşların vazgeçilmez unsurlarından biri uçaklar ve balonlar olmaya başlamıştır. $\mathrm{Bu}$ alan bir sanayi 
sektörü hâline gelmiş ve yüz binlerce insanın yoğun olarak üretim yaptığı çalışmalar başlamıştır. Osmanlı İmparatorluğunun ise en zayıf yönlerinden biri şüphesiz havacılık endüstrisinden yoksun olmasıydı. Ancak havacılık dışa bağımlı olarak da olsa cephelerde yerini almaya başlamıştı. Zamanla havacılık genişlemiş ve kara, balon ve deniz havacılığı ile de oldukça geniş bir alana yayılmış bir hava teşkilatı bulunuyordu ${ }^{1}$.

Türk Devleti açısından I. Dünya Savaşı'nın çıkış zamanı tam bir talihsizlik olmuştur. Savaş, dünya dengelerinin Türklerin aleyhine olduğu bir zamanda ve Osmanlı topraklarını paylaşma konusunda hırsın hâkim olduğu bir süreçte ortaya çıkmıştır. Ne var ki, Osmanlı İmparatorluğu'nun harbe girişi kamuoyunda tartışılmamış, tartıştırılmamıştır. Anlaş1ldığı kadarıyla iktidarı ellerinde tutanlar büyük baskılar oluşturmuşlar ve toplumun vicdanını dinleme ihtiyacı hissetmemişler. Savaşa karşı olduğunu bir binbaşı söylese konu Harbiye Nezaretine kadar taşınmakta ve binbaşı şahsi kanaatini söylediği için cezalandırılmaktadır. 4'üncü Kolordu Komutanlığından Kurmay Başkanı Binbaşı Cafer Tayyar Bey’e şahsi fikrini soranlara henüz erken, taraftar değilim dediği için uyarı cezası almıştır. (Artuner, 2005, s. 67). Türkiye'nin tehlikeli mecralarda olduğu dönemlerde doğrular yerine menfaat gruplarına çanak tutan basının

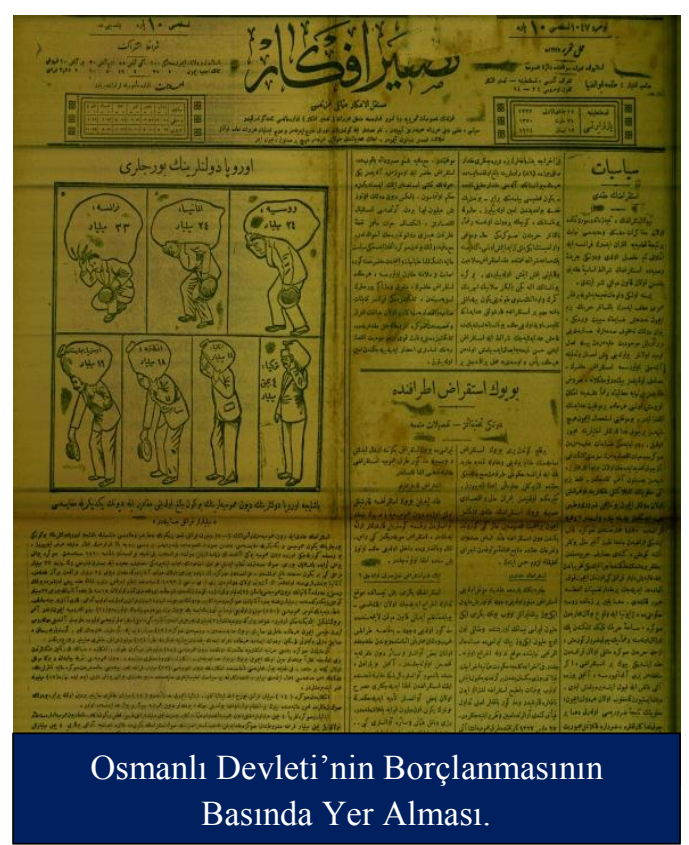
faaliyeti ayrı bir çalışma konusu olduğundan burada üzerinde durulmayacaktır.

Birinci Dünya Savaşı'nın tarafı olan güçlerin istatistiki verileri incelendiğinde İttifak güçlerinin uzun süreli bir savaş1 sürdüremeyeceği görülmektedir. Sayısal olarak da Osmanlı Devleti'nin taraf olduğu İttifak güçleri oldukça zayıftı. İttifak devletlerinin toplam nüfusu 168. 300. 000 kişi, asker sayıs1 ise 22, 9 milyondur. İtilaf devletlerinin ise toplam nüfusu 1. 002. 435. 000 kişi, asker sayıs1 ise 42, 7 milyondur. İtilaf devletlerinin imkân ve kabiliyetleri İttifak devletlerine göre kıyaslanamayacak kadar yüksektir (Çavuş, 2006, s. 14). Sanayi, zirai, eğitimli insan gücü, denizlere egemenlik ve ulaşımda sağlanan kolaylıklar bunlardan bazılarıdır.

\footnotetext{
${ }^{1}$ Gnkur. ATASE Arşivi, Birinci Dünya Harbi (BDH), 47 - 35 aa
} 
Birinci Dünya Savaşı'nın başında yeterli uçak, pilot, teçhizat ve teknik donanımı yoktu. Nitekim savaşın başında Yeşilköy Tayyare Mektebinde 5 - 6 tayyare bulunuyordu (Sözeri, 1962, s. 42; Yücel, 1963, s. 12). Ayrıca Hava Kuvvetleri üç yıllık bir geçmişi ile oldukça yeniydi. Teşkilatlanma henüz yapılanma aşamasındaydı. Pilot sayısı da 10 civarındaydı. Öte taraftan havacılık önce Fransızlara emanet edilmiş ama I. Dünya Savaşı'nda Osmanlı Devleti Fransa'ya karşı savaşa girdiğinden Osmanlı havacılığını 1slah etmekle görevli Fransız Yüzbaşı De Goys ülkesine gönderilmiştir. Savaş süresince Türk havacılı̆̆ı Alman Yüzbaşı Serno’ya emanet edilmiştir. Binbaşı Serno, savaş sonuna kadar askerî hava gücünün başında yer almıştır. Bir ara Batı Cephesi'ne görevlendirilmişse de Enver Paşa bizzat yeniden Türkiye'de görevlendirilmesi için girişimlerde bulunmuş ve görevine iade edilmiştir. Bu döneme ait ATASE arşivinde bulunan bir belge ekte sunulmuştur ${ }^{2}$ (Gnkur.ATASE Arşivi,BDH - 1425 $167 \mathrm{~A}-001-03 \mathrm{a})$.

İngiltere'nin, Vickers - Armstrong firmalarına yaptırılan 27.000 tonluk Sultan Osman ve 23.000 tonluk Reşadiye isimli savaş gemilerini son anda vermemesi (Tunçay - Akşin, 1990, s. 43; Palmer, s. 355) bu sırada benzeri bir olay da Fransa'ya sipariş edilen 15 adet uçağın başına gelmiştir. $\mathrm{Bu} 15$ deniz uçağına el konmuş ve uçaklar Fransız ordusuna teslim edilmiştir

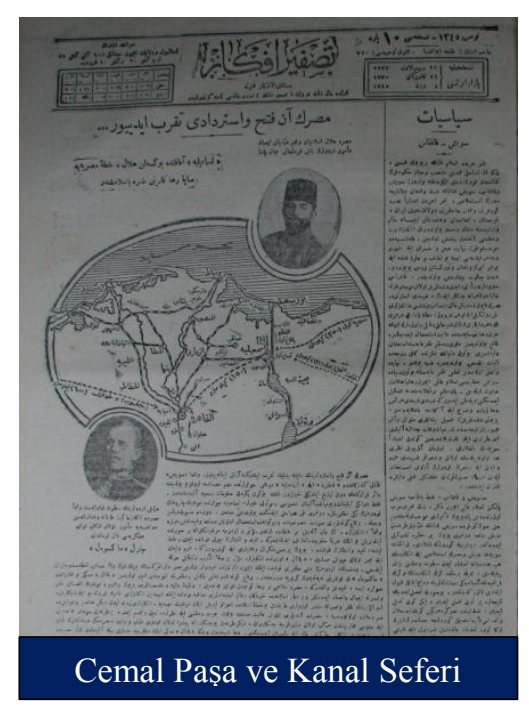

(Sarısır, 1998, s. 27). Bu uçaklar savaşta Osmanlı ordusuna karşı kullanılmıştır. $\mathrm{Bu}$ uçakların siparişi verildiği zamanlarda Fransa'dan büyük miktarda bir borç antlaşması yapılmıştı (Tasfir-i Efkar, 12 Nisan 1914). Bu istikraz antlaşması ile Osmanlı askerî malzemelerin bir kısmını Fransa'dan temin etmesi kararlaştırılmıştı. Konu uçakların bedeli de bu kapsamda ödenmiş olabileceği gibi Kıtalararası Hava Seferinde halkın bağışları ile toplanan yaklaşık 15 uçaklık ianelerden de ödenmiş olma ihtimali güçlüdür.

\section{1. Filistin Cephesi'nin Açılması}

Almanya ile 27 Temmuz 1914'de başlayan görüşmeler 2 Ağustos 1914'de bir ittifak ile neticelenmiştir. Beş y1l süreli ittifakta Avusturya ve Rusya savaşa tutuşur da Almanya savaşa girerse Osmanlı İmparatorluğu da savaşa katılacaktı. Keza Osmanlı İmparatorluğu tehdit altında

\footnotetext{
${ }^{2}$ Serno'nun Almanya'da Görevlendirilmesi ve Aldığı Nişan Gnkur. ATASE Arşivi (BDH - 1425 - 167A - 001 - $03 a$ ), Serno'nun Almanya'da Görevlendirilmesi ve Aldığı Nişan.
} 
kalırsa Almanya Osmanlı İmparatorluğunu silahla savunacaktı (Yılmaz - Kılınçkaya, 2008, s. 105). Savaşın başlaması ile birlikte Osmanlı İmparatorluğu tarafsız kalmak için bir süre direnmişse de Goeben ve Breusleu isimli gemiler olayların seyrini değiştirmiştir (Yılmaz vd., 2008, s. 106; Artuner, 2005, s. 68).

Savaşın başlaması ile birlikte Enver Bey, Almanya'dan havacılık sistemleri siparişine önem vermiştir. Almanya ile yapılan 11 Kasım 1914 tarihli mesajlaşmada gönderilmesi kesinleşen uçaklarla Alman ordusundaki fazla teçhizatlardan gönderilmesi kararlaştırılmıştır (Keyüsk, 1951, s. 19). Devrik Hidiv Abbas Hilmi Paşa, İngilizlerin Osmanlı ve İngilizlere karş1 isyan eden Mısırlıların ateşi arasında kalacağı konusunda Cemal Paşa'yı ikna etmişti. Anılarında herkesin kanalın geçileceğini ve Mısır vatanseverlerinin de ihtilal ederek kendilerine katılması ile İngilizlerin pek büyük sıkıntıya düşeceğini ve zaferin kazanılacağına olan beklentileri anlatır (Kabacal1, 2010, s. 181, 182). Esasen bir y1l önce icra edilen Kitalararas1 Osmanlı Hava Seferi'nde her yerleşim yerinde ve gösteri merkezlerinde yüz binlerin meydanları

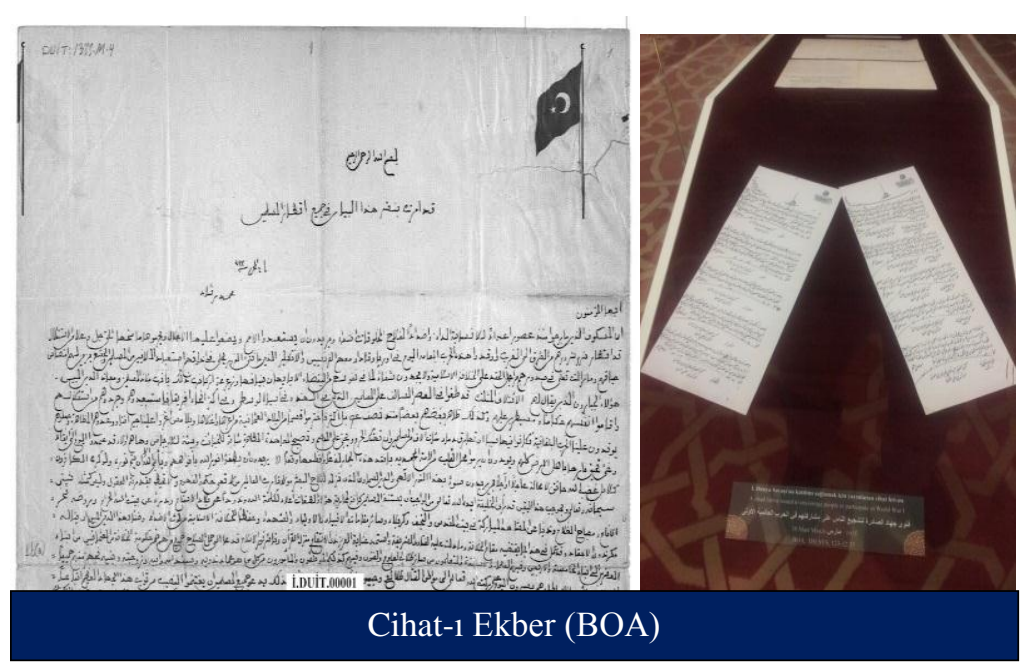
doldurmasının etkisi ve idareci kesimde oluşturduğu intiba bu bakımdan araştırılmaya muhtaçtır.

İngilizlerin en büyük korkusu Osmanlı İmparatorluğu Padişahı'nın halifelik sıfatı ile "Cihad-ı Mukaddes" ilan ederek (BOA, DHSYS, 123 - 1235, 10 Mart 1915; BOA, İ_DUiT_00001_000028_002_001) büyük isyanlara sebep olmasıydı. Bu fetva birçok dilde yazılarak ilgili ülkelere gönderilmiştir. İngiltere bu tarihte dünyada en çok Müslüman'ın yaşadığı bir ülke olarak riskleri doğru analiz edip tedbir almak durumundaydı. Kanal Taarruzu haberini almış olduklarından 18 Aralık 1918'de Mısır'1 himayelerine aldıklarını ilan ettiler. Hidiv II. Abbas Paşa'yı iktidardan uzaklaştırarak amcası Hüseyin Kamil Paşa'yı Sultan ilan ettiler (Kansu, 1971, s. 174). Kanal Cephesi Komutanı Cemal Paşa'nın anılarında Kanal'ın nasıl geçileceği konusunda bir fikri altyapının olmadığını, düşmanın ve kendi imkânlarının mukayese edilmediğini belirtmesi düşündürücüdür (Kabacalı, 
2010, s. 187). Ancak Cemal Paşa'nın Mısır'1 alma ve ele geçirme konusunda ise oldukça inancının güvenli olduğu anlaşılmaktadır (Artuner, 2005, s. 127).

\section{1. Savaşın İkinci Yılında Filistin Cephesinde Hava Harekâtı}

Filistin Cephesi'nin ilk önemli harekâtı Süveyş Kanalı'nı geçerek Mısır topraklarına yönelik olarak daha ziyade Almanların talebi ile gerçekleştirilen seferdir. Cemal Paşa komutasında oluşturulan ordu ile İskenderun'dan Kanal'a ve Akabe'den bütün Arabistan ile Suriye'yi içine alan bir sahanın denetimini ve korunmasını sağlaması kararlaştırılmıştı (Kansu,

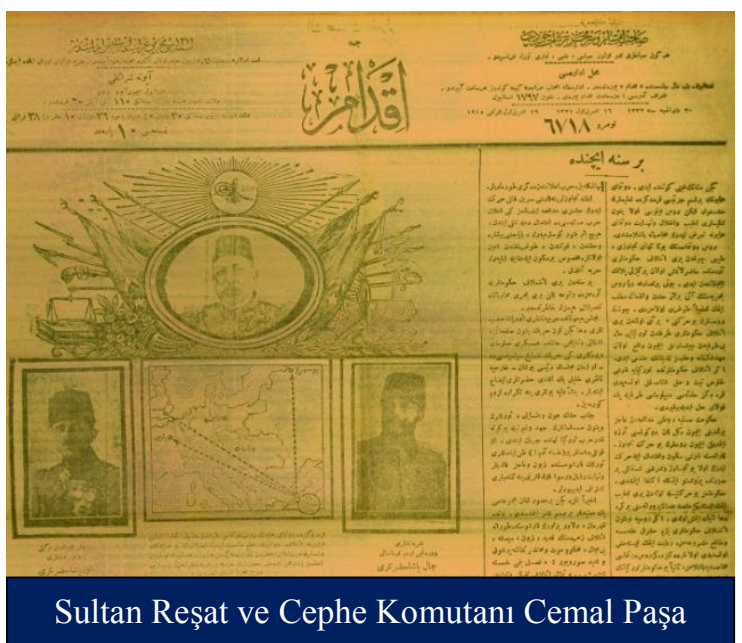
1971, s. 254). 4'üncü Ordu Komutanı Cemal Paşa, 30 Mart 1915 tarihinde Başkomutanlık Vekâleti'ne yazmış olduğu yazıda mevcut eski ve arızalı 2 tayyare ile gelişmiş İngiliz uçakları karşısında Kanal Harekâtı yapılamayacağını belirterek yeni tayyareler gönderilmesini, hiç olmazsa bir tayyare gönderilmesini talep etmiştir. Başkomutanlık Vekâleti 16 Haziran 1915'de vermiş olduğu cevapta tayyare mevcut olmadığından yenisinin gönderilemeyeceğini belirterek, arızaların neler olduğunun bildirilmesini istemiş ve giderilmemesinin mümkün olup olmadığını sormuştur. (Keyüsk, 1951, s. 83 - 86). Bu dönemde merkezden uçak göndermenin imkânsızlığı karşısında Osmanlı ordusu, ele geçirdiği uçakları faal etmiş ve bu uçaklar İngilizlere karşı kullanılmıştır. Takiben Aralık ayında temin edilen uçaklar bölgeye Türk ve Alman pilotlarca ulaştırılabilmiştir.(Kansu vd., 2006, s. 212).

Cemal Paşa, Mısır'a yönelik Kanal Harekâtı'na ümit bağlamıştı. Türk askerleri tombazlarla Kanal'ı geçerek Batı tarafinda yer alan İngiliz mevzilerini ele geçireceklerdi. İngilizler ise bölgede önemli tedbirler almış bulunuyordu. Mısır'da 30. 000 Hint askeri olmak üzere 150. 000 İngiliz askeri bulunuyor ve bunlardan 35. 000 asker yalnız Süveyş Kanalı'nı gözetmekle görevlendirilmişti. Altı İngiliz harp gemisi Süveyş Kanalı boyunca devriye gezerken kanal boyunca döşenen demir yolu hattında zırhlı trenler de devriye gezmekteydi. Bölgede İngiliz ve Fransız hava kuvvetlerinden uçaklar da bu tarihlerde görev yapmaktaydı. 3X İngiliz Farman uçağı ile Fransız "Foudra Uçak Ana Gemisi” bölgedeydi (Kansu, 1971, s. 174, 209). 


\section{1. 1. Birinci Kanal Harekâtı (14 Ocak - 15 Şubat 1915)}

Cemal Paşa, Kanal Harekâtı'ndan çok ümitlidir. Harekât ordunun yeniden mevzilenmesine kadar bir ay sürmüştür. Harekât başlarken Çöl azığı hazırlanmış ve bu

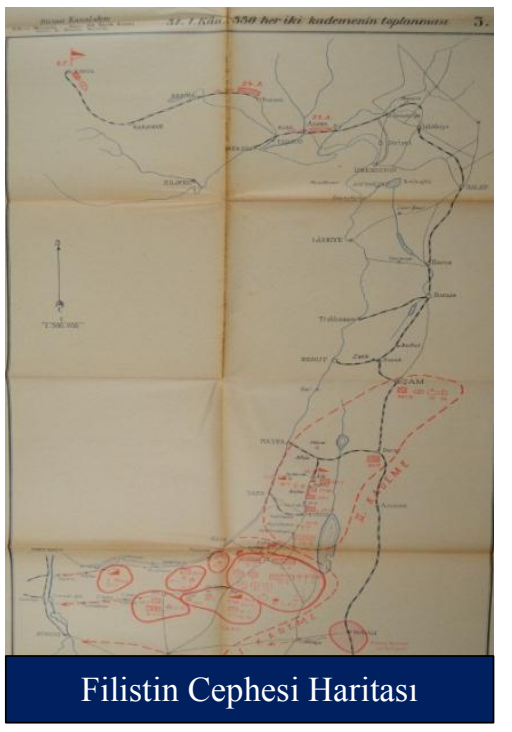
kapsamda adam başına 600 gram peksimet, 150 gram hurma, 9 gram çay ve 4 kilo su planlanırken atlar için 5 kilo arpa ve 18 litre su, deve başına 3 kilo arpa ve 5 kilo su planlaması yapılmıştır. Planlamada 9000 deve olmasına rağmen bu rakam 5. 000'i ancak bulmuştur (Miralay Muzaffer, 1934, s. 10, 11; von Kress, 2007, s. 97 - 100; Altın, 2014, s. 226). Özellikle kanal harekâtının ilk safhasında Mısır'ın bütün samimiyetleri ile Osmanlı ordusunu beklediği ordu birimlerinde de bir kanaat hâline gelmişti. "Mısırlılar bizi çağırıyor.” Soğuk Şubat günlerine rağmen geç kalınmaması savunuluyordu (Miralay Muzaffer, 1934, s. 15).

Çölde yapılan harekât oldukça zorluklar içinde geçiyordu. Sibestiya-İstasyonu ile Sebi arasında yapılan taşımacılık günde 30 tondu. Oysa günlük erzak ihtiyacı 90 tondu. Su ihtiyacı ile bu 250 tona ulaşıyordu. Ancak bu sevkiyatı yapacak yük hayvanı ya da yeterli yük taşıma devesi (hecin) bulunamıyordu (Miralay Muzaffer, Askeri Mecmua, S. 92, 1934, s. 33) ${ }^{3}$. Kanal Taarruzu, 2 Şubat 1915 tarihinde başlamıştır. Kanal'ın batısına geçen 74'üncü Alayın bir bölüğü imha ve esir edilmiştir. Geçişlerde Tonbazlar kullanılması planlanmıştı. Harekâtın başarısız olacağı konusunda Cemal Paşa'ya bilgi veren Kurmay Başkanı Albay Fon Kress (Von Kress) taarruza şeref için devam edilmesini önermektedir. Ancak Ordu Komutanı askerin heba edilmesini doğru bulmamıştır. Bu harekâtta Birüssebi'de dört uçak bulunuyorsa da destek vermeleri mümkün olmamıştır (Göymen, 1969, s. 64; Iş1k, 2014, s. 230 - 232).

\section{1. Savaşın Üçüncü Yılında Filistin Cephesinde Hava Harekâtı}

1916 yılına girildiği zaman İtilaf orduları Çanakkale Cephesi'nde büyük bir yenilgiye uğratılmıştı. Kafkas Cephesi'nde durum oldukça tehlikeli bir durumdaydı. Ruslar Van ve daha güneylere kadar ilerlemiş durumdaydı. Erzurum'a uzanan menzil hattına gerekli yığınakları yapmak için fazla bir zaman kalmamıştı. Irak Cephesi’nde ise Salmanpak Muharebeleri

\footnotetext{
${ }^{3}$ Haritada Birinci Kanal Harekâtında tarafların durumu gösterilmektedir. Askeri Mecmua Sayı:92
} 
kazanılmış olmasına rağmen kuzeye ve güneye doğru yayılan İngilizlere karşı büyük bir savunma hattı oluşturulması önem arz etmekteydi. (Keyüsk, 1951, s. 99; Türkmen, 2015, s. 404 - 406). Osmanlı ordusunun 5 Ağustos 1916'da Hava Kuvvetleri öncülüğünde başlatmış olduğu taarruza "Romani Taarruzu" adı verilmektedir. Harekât yılın sonuna kadar bazen hareketli bazen de sükûnet ile geçmiştir. Ancak İngilizlerin aldığı geniş tedbirler ile Türk ordusu GazzeBirüssebi Hattı'na çekilmek durumunda kalmıştır (Göymen, 1969, s. 117 - 119)..

Türk havacıların eğitim tarzında önemli değişiklikler 1916 yılında gerçekleşmiştir. Daha önce yerde tarif üzerine kendileri direkt uçuşa çıkan pilot adayları büyük risk almaktaydılar. Bunun nedeni ise uçakların tek kişilik olmasıydı. 1916 yılında Almanya'dan çift kişilik tayyareler getirilmiş ve eğitimlerin uygulama kısmında da öğretmen ve aday pilotlar beraber uçmaya başlamıştır. Osmanlı havacılığı savaş yıllarında teşkilat ve teçhizat olarak büyümüştür. Havacıların kendilerine has yeni alametleri ve işaretleri de gelişme göstermiştir. Bröveler ve kimlerin takabileceği belirlenmiştir ${ }^{4}$ (ATASE, BDH, 1425 - 167A - 001 - 01a).

Filistin Cephesi birçok bakımdan diğer cephelerden farklılık arz etmekteydi. Birüssebi ve Gazze istikametinde Osmanlı ordusu tarafından sefer hattına demir yolları hattı döşenmiş, şoseler ve özel yollar yapılmış, menzil hattı boyunca hastaneleri, iaşe merkezleri, erzak ambarları, melbusat ve teçhizat depoları inşa edilmiştir. Güneye doğru ilerledikçe su sorunu büyüyordu. $\mathrm{Bu}$ nedenle buralarda su kanalları açılmasına ve borularla suyun ileri hatlara iletilmesine çalışılmıştır (Keyüsk, 1951, s. 166; Göymen, 1969, s. 111). Von Kress'in anıları da bu süreci oldukça detaylı olarak vermektedir. Osmanlı ordusu bazı dikkate değer tedbirler alırken İngiltere de önemli hazırlıklar yapmıştır. İleriki kısımlarda, çok daha şümullü bir faaliyet içinde oldukları müşahede edilecektir.

Suriye ve Filistin Cephelerinde fenni ve teknik olanakların en son hâlinin kullanılması gerekirdi. $\mathrm{Bu}$ maksatla Alman ordusundan yararlanmak önem arz etmekteydi. Yapılan görüşmeler sonucunda Alman Başkomutanlı̆̆ı, "Paşa Kuvvetleri” adıyla seferi kuvveti Filistin Cephesi'ne göndermiştir. Bu kuvvet içinde hava unsuru da bulunuyordu. Bu hava unsuru “300’üncü Paşa Bölüğü” olarak adlandırılmıştır (Kansu, 1971, s. 260). Zamanla Tayyare Paşa Bölüklerinin sayısı 5'e çıkmıştır. 300'üncü Paşa Bölüğünde Yzb. Hemskerk komutasındaydı ve bölük envanterinde 14 adet Mercedes motorlu Rumpler tayyaresi bulunuyordu. Tayyarelerin cepheye ulaşması da güçlükler içinde olmuştur. Sırbistan bu tarihlerde mağlup olduğundan ve

\footnotetext{
${ }^{4}$ Arşivi, 1916'da Kabul Edilen Osmanlı Havacılarının Alametleri ve İşaretleri
} 
Bulgaristan, Osmanlı İmparatorluğu'nun dâhil olduğu İttifak grubu içinde yer aldığından Almanya'dan İstanbul'a doğrudan tren yolu hattı çalışmaya başlamıştır. Bu uçaklar İstanbul'dan Bağdat'a yollanmıştı.

21 Nisan 1916'da Uğratina ve Katya taraflarında İngilizlerin kara unsurları ağır yenilgiler almışlardı. Oysa bu hareketin devamlılığ için hava keşfinin kesintisiz sürmesi gerekiyordu.

İngilizler tarafından hava taarruzları yaz boyunca yoğun olarak sürmüştür. Türkler bu saldırılara karşı topçu birlikleri ve hava bölükleri ile karşılık vermişler ve İngilizler birçok uçak kaybına maruz kalmıştır. Örneğin 29 Mayıs'ta bir İngiliz uçağını Osmanlı piyadesi düşürmüş, yine Haziran ayı içerisinde 3, 13, 14, 18 Haziran tarihlerinde karşı1ıklı taarruzlarla İngilizler birçok uçaklarını kaybetmiştir. Bu hava savaşlarında 300'üncü Tayyare Bölüğü etkin bir hava hâkimiyeti sağlarken, Osmanlı kara unsurları da önemli hava savunma görevi yapmıştır. 3 Temmuz 1916 tarihinde baskın yapılarak Türk ordugâhı bombalanmıştır. Bu esasen başarılı bir baskın sayılmaz. Çünkü baskın, hemen öncesinde gözcüler tarafından bildirilmiş ve yerden uçaklara karşı yoğun bir ateş hüzmesi başlatılmıştır. Ayrıca bu baskında 3 İngiliz uçağ1 düşürülmüştür (Kansu, 1971, s. 261; Keyüsk, 1951, s. 167, 172 - 177; Göymen, 1969, s.113 116; von Kress, 2007, s. 200 - 202). İkinci Kanal Harekâtı öncesi Sina yarımadasına kadar deniz ve kara yolu yapılmış, su sorunu çözülmeye çalışılmıştır. Kuyu açılması veya ordunun harekât alanına su boruları ile döşenmesi, hava gücünün bölgede konuşlanması bu kapsamdadır (Taşkıran, 2011, s. 33).

\section{1. 1. İkinci Kanal Harekâtı (27 Temmuz 1916-05 Ağustos 1916)}

Alman Miralayı Kress von Kressenstein'in komutasındaki 10. 000 kişilik bir kuvvetle gerçekleştirilir. Kress ile ilgili olarak daha önce ifade edildiği gibi Birinci Harekâtı şeref uğruna sürdürmek istemiş ancak ordu komutanı Cemal Paşa'nın yenilen ve varlığı sona eren bir ordunun şerefinden bahsedilemeyeceği gerekçesiyle 3 Şubat 1915 tarihinde ilk harekat fiilen sona ermişti. Kress anılarında cephede alan kanın İngilizler ile Türkler arasındaki husumeti artıracağ1 ve Türklerin müttefiklik ruhunu güçlendireceği kanaatine sahiptir ve yeni bir harekât1 önemsemektedir (Westwell, 2014, s. 102, 103).

Harekât, 5 Ağustos sabahı 300'üncü Paşa Tayyare Bölüğünün düşman mevzilerini bombalaması ile başlar. İki İngiliz uçağı düşürülürken, biri de kendi mevzileri gerisine inmek zorunda kalır. $\mathrm{Bu}$ tarihte ikinci harekâttan beklenen faydayı görmeyen Osmanlı birlikleri El- 
Ariş’e çekilmiştir. $\mathrm{Bu}$ tarihten itibaren İngilizlerin bölge üzerindeki tazyikleri artmış ve kademeli olarak Osmanlı ordusu çekilmeye başlamıştır. Bu harekâtta Osmanlı güçleri esirler dâhil 4.000, İngilizler ise 1.130 zayiat vermiştir (Taşkıran, 2011,s.35).

\section{1. 2. İkinci Kanal Harekât Sonrası Gelişmeler ve Osmanlının Bir Coğrafyadan Çekilişi}

Kanal Cephesinde alına mağlubiyet sonrasında Osmanlı ordusu beklentisini elde edememiştir. Savaş başlarken öngörülen hususlarda da önemli sapmalar olmuştur. Osmanlı

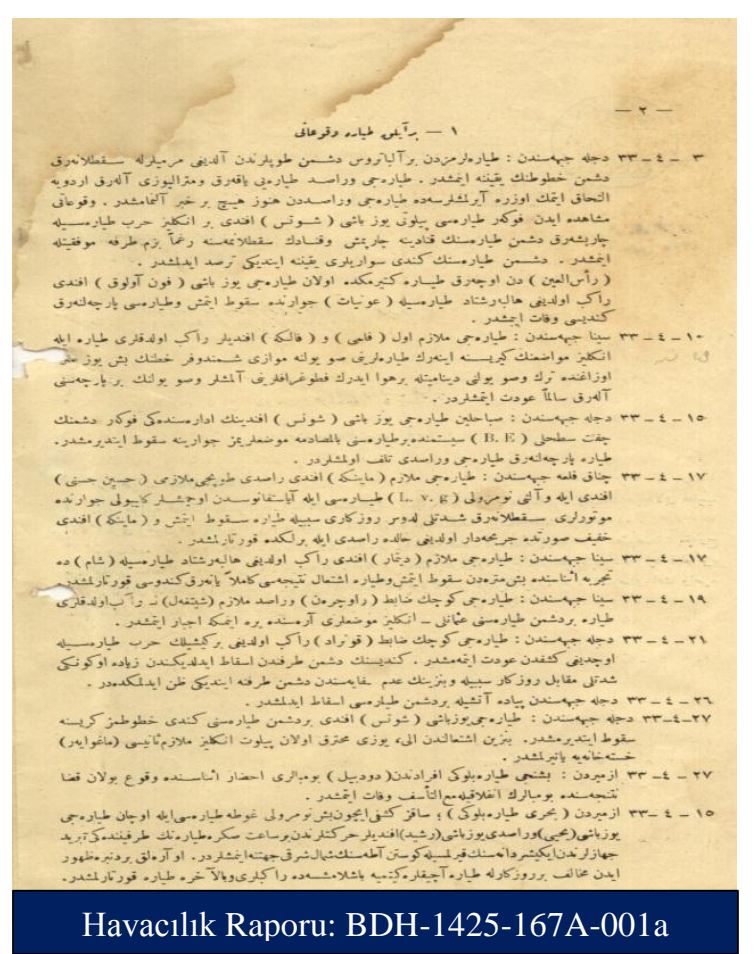
ordularının ileri harekâtı bölge halkından başlamak üzere bütün İslam dünyasında bir başkaldırı ve İtilaf güçlerine karşı büyük muvaffakiyetler beklenirken aksi bir durumla neticelenmiştir.

Kara unsurunun geri çekilme sürecine rağmen göklerde hava muharebesi sürmüştür. $\mathrm{Bu}$ süreçte; 6 Ağustos 1916'da düşman ordugâhına 30 bomba atılmıştır. Türk uçaklarının tazyiki yıl boyunca devam etmiştir. Bu dönemde cephede yer alan İngiliz uçak sayısı 30'dur. Hava Kuvvetleri Komutanlığ 1 tarafından 1940’lı yıllarda Birinci Dünya Savaşı'na rasıt olarak iştirak eden Mazlum Keyüsk’e Türk havacılığının ilk yıllarının (1911 - 1918) tarihi arşiv belgelerinden yazdırılmıştır. Keyüsk çalışmasını ATASE arşivlerinden yararlanarak hazırlamıştır. Sonraki yıllarda Atase'nin tasnif yöntemi değiştiğinden ve o yıllarda günümüzdeki şekilde kaynakları referans olarak kullanma yöntemi bulunmuyordu. Keyüsk'ün eserinde rapor olarak geçen ve özetle Ekim 1916'da İngilizlerin büyük bir tazyikle taarruza hazırlandıkları bildirilmektedir. Türk ordusunun ihtiyacı olan kargir binaların bir an evvel tamamlanması Kuvve-i Seferiye Komutanlığından istenmektedir. Raporun devamında Sina'da yer alan büyük kuvvetlerin iaşe yolsuzlukları nedeniyle idame ettirilemediğinden Filistin'in kuzeyine doğru gerilere alındığı bildirilmektedir (Kansu, 1971, s. 262; Keyüsk, 1951, s. 183; Göymen, 1969, s. 115). Dönemin önemli raporlarından biri de hava kuvvetlerinin faaliyetlerine ait performans tablosuna ait olanıdır. Raporlarda uçakların faaliyeti ve personel 
isim olarak belirtilerek kişisel başarıların Genek Karagaha bildirilmesi yapılmaktadır. Düşürülen uçakların listesi Kaymaklı'nın eserinde detaylı yer almıştır. Ayrıca aylık hava raporlarında da düşürülen uçaklara yönelik bilgiler verilmektedir.(Gnkur. ATASE, BDH - 1425 - 167A - 001a).

27 Kasım 1916 tarihinde yapılan keşifte İngilizlerin demiryolunu Elariş istikametinde inşasına ihtimam gösterilmesi ve süratle ilerlemesi, İngilizlerin Filistin'e yönelik emelleri olduğunu göstermekteydi. Bu durum karşısında Osmanlı Devleti, ön almak ve olası bir taarruza hazırlanmak için tedbir almaya başlamıştır. Türk ordusunun en önemli sorunu yedek parça ve silah sistemine ilave olarak askerin beslenme sorunu olmaya başladığından 1 Aralık 1916 tarihi itibariyle er yemek istihkakı günde 500 grama indirilmiştir (Kansu, 1971, s. 263; Keyüsk, 1951, s. 184).

Aralık 1916 tarihi, Türk havacıları ve topçularının birçok İngiliz uçağını düşürdüğü bir dönem olmuştur. Ancak 17 Aralık 1916 tarihinde İngilizler Elariş’e girmiştir ve kasaba önünde de küçük bir donanma demir atmıştır. Bu gelişme üzerine Kuvve-i Seferiye Komutanlığınca Elariş Mevki Komutanlığına verilen emir gereği Türk birlikleri Zara ve Elariş’i tahliye etmiş ve Maktaba'ya çekilmiştir. Çekilme emrinde malzemelerin düşmana bırakılmaması için geri alınması veya imhası istenmiştir. Birüssebi'de bulunan tayyare bölük tamirhanesi Remle'ye çekilirken Birüssebi, meydan statüsünü korumuştur. İngilizler bu dönemde süvari bakımından oldukça yeterlidir. İaşe ve malzeme desteği trenlerle ve gemilerle yapılabilmekteydi. Bu durumun sonucu olarak alan hâkimiyetini ellerinde tutuyor ve istedikleri yerde sıklet merkezi oluşturabilecek imkâna sahip bulunuyorlardı. İngilizlerin bir diğer avantajı ise yerli Arapların isyanını kullanmaları, Şerif Hüseyin'in Hicaz'dan Suriye'ye kadar uzanacak Arap İmparatorluğu hayaline bir süreliğine destek vermeleriydi. Haziran 1916'da Şerif Hüseyin'in resmen isyan ettiği bir zamanda İngiltere İkinci Kanal Harekâtını etkisizleştirirken mukabil taarruza başlamış bulunuyorlardı (Kansu, 1971, s. 264; Artuner, 2005, s. 138).

Filistin Cephesinde faaliyet gösteren bir diğer hava bölüğü 3’üncü Hava Bölüğü olmuştur. Bu bölük Medine'deki ayaklanmaya karşı görev yapmak üzere teşkil edilmiş ve Hicaz Seferiye Kuvveti emrine verilmek üzere hazırlanmıştır. 23 Haziran 1923'te birinci kademe İstanbul'dan hareket etmiştir. Bu dönemde 4'üncü Ordu Komutanı Cemal Paşa da Havranlıların isyan emareleri üzerine Filistin Cephesi için hava bölüğü talep etmektedir. Bu talep üzerine Medine için ayrılan tayyareler Dera'da konuşlanmış ve kısa sürede aktif hâle getirilmiştir (Keyüsk, 1951, s. 192 - 199; Keyüsk, 1952, s. 257). 
$570^{* \text { TAED }} 55$

Osman YALÇIN

13 Ağustos 1916 tarihli 4’üncü Ordu Komutanı Cemal Paşa'nın Başkomutanlık Vekâleti’ne gönderdiği yazıda Medine için 3'üncü Bölükte bulunan uçakları göndermek yerine hiç göndermemenin daha iyi olduğunu, Medine için yeni ve modern uçakların gönderilmesini talep etmiştir. Fazıl Bey, Medine'de başarılı uçuşlar yapmış ve 3'üncü Bölük komutanı olarak asaleten ataması yapılmıştır. Fazıl Bey, 1916 yılının son aylarında Medine bölgesinde yoğun uçuşlar yaparak İngilizler ve Urban hakkında keşiflerde bulunmuş, havadan taarruzlar yapmıştır.

1916 yılı Nisan ayının ilk günlerinde Almanya'dan gelen 300’üncü Tayyare Bölüğü Bîrüssebi'ye gelir ve konuşlanır. Von Kress anılarında bu durumu İngiliz hava taarruzuna karşı Osmanlı hava etkinliğinin artması ve keşif yapılması için önemli bir kazanç olarak değerlendirmektedir (von Kress, 2007, s. 180, 181). 1916 yılında havacılık harekât bakımından 13'üncü Umuru Haviye Şubesi marifetiyle yürütülmektedir. Genel Karargâhı'nın 22 Aralık 1915 tarihinde 13'üncü Şubeye Kıbrıs Adası üzerine uçma imkânı ile Adana'ya müfreze gönderme imkânı olup olmadığı bilgisini sorması ile 4'üncü Tayyare Bölüğünün kuruluş çalışması başlatılır. Alman Gizli Teşkilatı, İngilizlerin Adana ve İskenderun bölgesine çıkarma yapacağı istihbaratını Osmanlı Genel Karargâhına iletir. Bu gelişme üzerine Umur-u Havaiye Şubesi 2 uçaktan oluşan Tayyare Müfrezesini Üsteğmen Mithat Nuri ve Alman hava subay1 Roder pilot olarak temsil etmektedir ve Mithat, müfreze komutanıdır. İki Alman makinist de müfrezeye dâhil olmuştur. Tayyareler trenle Pozantı'ya getirilmiş, tüneller açık olmadığından buradan araba üzerinde Tarsus yakınındaki Kölek istasyonunda faaliyete başlamıştır (Kansu, 1971, s. 254, 320; Keser, 2013, s. 170 - 172). Bu müfreze 4'üncü Tayyare Bölüğü’nün nüvesini teşkil etmiştir. Drama'dan Sina - Filistin'e Savaş Günlügü isimli hatıratın yazarı Sami Yengin savaşın son iki yılında Filistin Cephesi'nde görev almış bir askerdir. Hatıratında yaşadıklarını günü gününe yazmaya çalışmış ve bu günlükler incelendiğinde bulunduğu birliği huzursuz eden en büyük tehlikenin havadan geldiği ve İngiliz uçaklarının bazen keşif maksatlı bazen bombalama yapmak üzere geldiği bilgisi sıklıkla hatıratta yer alır (Yengin, 2007, s. 1 - 100)

Filistin Cephesi'nde 1916 yılında bazı hareketlenmeler olmakla birlikte bir tarafin diğer taraf üzerinde kesin üstünlük kurulamamıştı. Yakın bir Cephe olarak Irak Cephesi de önemli gelişmelere adaydı. Irak Cephesinde yapılan çalışmalar Filistin Cephesini doğrudan etkilemekte olduğundan burada yaşanan gelişmeleri dikkate almak önemliydi. İngiliz kamuoyu Arap toprakları üzerinde yapılan mücadeleler ve genel olarak Osmanlı İmparatorluğu ile yapılan savaşta farklı beklentileri olduğundan bölünmüş hâldeydi. Halkın duygusuna tercüman olan bir kesim Osmanlı toprakları üzerinde büyük bir zafer kazanılmasını istiyordu. Esasen Çanakkale 
Zaferi üzerine yıkılan imajları bunu zorunlu kılıyordu. Bir kesim İngiliz ise Fırat ve Musul'daki petrol sahalarının işgalini isterken üçüncü grup İran üzerinden Hindistan'a açılan bir sömürge yolu olmasını istemekteydi. Bu maksatla 1916 yılı içinde önemli çalışmalar yapılmıştır. (Keyüsk, 1951, s. 249). Filistin Cephesi ve Irak Cephesi birbirine yakın coğrafi alanlarda oluşturulmuştur. Türk Havacılık tarihinden alınan bilgiler İngilizlerin harekât ortamında lojistiğe verdikleri önem bakımından dikkate değer bilgilere sahiptir. Bu kapsamda İngilizler tarafından Irak Cephesi’nde yapılan hazırlıklar şunlardır (Keyüsk, 1951, s. 253, 254):

a) İngiltere'den 17.000 ton cephane getirilmiştir.

b) Askerlere her gün taze ve dondurulmuş soğuk et yedirilecek tedbirler alınmıştır. 20.000 dönüm arazide sebze bostanları oluşturulmuştur.

c) Kanatlı hayvanat sürüleri yetiştirilmiştir.

d) 16.000 kişilik hastane kapasitesi elde edilmiştir.

e) Buz fabrikaları kurulmuş,

f) Ordugâhta vantilatör, cibinlik ve tel kafesi ile sihhi şartlar ve konforlar artırılmıştır.

g) Basra Limanı açık deniz limanları oluşturulmuştur. 5.000 metrelik bir rıhtım yapılmıştır. Yeni depolar yapılmış ve buharlı nakliye vasıtaları ile güçlendirilmiştir.

h) Dicle üzerinde 1.000 kadar istimbot hazırlanmıştır. Nakliye genelde nehirlerden yapılmış ve kara taşımacılığı minimum seviyeye düşürülmüştür.

i) Basra'dan Fırat üzerinde Nasriye'ye, Dijle üzerinden Ammare'ye kadar bir metre genişliğinde, Bilahare buradan ilerisine $60 \mathrm{~cm}$.lik Essine ve Dicle istikametinde iki istikamette (Gidiş - Geliş Hatları) 771 km.lik demir yolu yapılmıştır.

j) Hava Meydanları tesis edilmiş, muharip uçak filoları artırılmış ve tamirhaneler yapılmıştır.

k) Taarruz öncesi 65.000’i menzilde, 95.000’i ileri hatta olmak üzere 160.000 asker toplanırken top miktarı 28'i ağır 176 adede yükselmiştir. Bunun karşıllı̆ında bölgede bulunan Türk askeri sayısı İngilizlerin 1 / 10'u kadardı. Yılın son aylarında Türklerin 2'nci Tayyare Bölügü ve İngiliz hava gücü arasında hava muharebeleri yapılmıştır.

1916 yılında Irak Cephesi'nde yapılan hazırlıklar hemen hemen diğer cephelerde de yapılmaya başlanmıştır. Filistin Cephesi ve Irak Cephesi savaşın sonuçları bakımından birbirine 
benzer gelişmelerin yaşandığ 1 cepheler olmuşlardır. Ortadoğu'nun geleceğinin planlandığı gizli antlaşmalar iki cephenin harekât alanı üzerinde yoğunlaşmıştır.

Savaşın uzaması ve İngilizlerin stratejilerini geliştirmeleri ile 1916 ortalarına kadar daha etkin olan İttifak güçleri dinamizmini kaybetmeye başlamıştır. Amerika'nın da harbin tarafı olması bu günlerde önemli konuların başında yer almaktadır. Amerika Birleşik Devletleri'nin savaşa çekilmesi İttifak güçleri bakımından ciddi bir talihsizlik olmuştur. ABD’nin savaşa çekilmesi ise Almanya'nın uygulamış olduğu politikanın bir sonucu olmuştur. Bu sonuç, zinde ve güçlü bir ordunun yorulmuş kuvvetler karşısına çıkarak dengeleri değiştirmesine neden olmuştur. Yine bu kapsamda İngilizlerin Filistin ve Irak Cephelerine daha fazla eğilmeleri, güçlendirmeleri ve teçhizat olarak da yeniden yapılandırmaları gibi hayati sonuçları olmuştur. Takip eden tarihlerde havacılık da bu alanda desteklenen önemli alanlardan biri olmuştur.

\section{1. Savaşın Dördüncü Yılında Filistin Cephesinde Hava Harekâtı}

1917 yılında Osmanlı Havacılığı teşkilat olarak büyümüştür. Yüzbaşı rütbesi ile Osmanlı Hava Gücünün sevk ve idaresini devralan Erich von Serno bu tarihte müstakil tümen seviyesinde bir hava gücünün komutanı mevkiini işgal etmektedir. 31 Aralık 1916 tarihli nizamname ile havacılığın sevk ve idaresine ait hususlar Sultan Reşat tarafından onaylanmıştır (Keyüsk, 1952, s. 10 - 12).

1917 yılı Ocak ayı başlarında İngilizler ileri harekâta başlarlar; ancak bu harekâtta gündüzleri gizlenerek, geceleri ilerler ve Türk tayyareleri bu durumu keşfedemez. Tellürefah üzerinde 9 Ocak 1917 'de bir İngiliz uçağı düşürülür. İngilizler hava gücü olarak üstünlüklerini ve sayısal güçlerini korumaktadırlar. Hatta II. Dünya Savaşı yıllarında yoğun olarak uygulanan Stratejik Hava Kuvvetleri konseptinin ilk uygulamalarının izleri Filistin Cephesi'nde rastlanmaktadır. Burada konuşlu olan Avustralya Tayyare Bölüğü uzak bölgelere giderek keşif ve bombardıman vazifesi yaparken, diğer bir tayyare birliği yakın menzil içinde topçu ateşi tanzimi ve taktik alanda kullanılmak üzere istihdam edilmiş bulunuyordu (Göymen, 1969, s. $189,190)$.

Filistin Cephesi'nde 1917 yılında Gazze Muharebeleri olarak anılan 3 ayrı muharebe cereyan etmiştir. Bu muharebeler İtilaf güçlerinin bölgeye yönelik yoğunlukları ve bölgenin savunmasını üstlenen Osmanlı ordusu için önemli gelişmelerdir. Sonuçları bakımından da Osmanlı İmparatorluğu ve bölge için kalıcı etkileri olmuştur. Bu muharebelerin cereyan şekli ve hava kuvvetleri açısından etkileri bu çalışmada kısaca anlatılmıştır. 


\section{1. Gazze Muharebeleri}

Kanal Seferleri (1. ve 2. Kanal Harekât1), Romani muharebeleri ile İngilizler, Osmanlı güçleri karşısında inisiyatifi ele geçirmişlerdir. Kanalın batısında egemen olan İngilizler 1917 yılı başlarında Süveyş Kanalı doğusuna da yayılmaya başlamışlardı (Westwell, 2014, s. 102, 103). Yavuz Sultan Selim ve güçlü ordusunun 400 y1l önce Batı'ya doğru ilerleyerek 1517'de egemenlik kurduğu bölgeden Osmanlı ordusu 1917'de bu kez ters istikamette doğuya çekilerek bölgeyi İngilizlere terk etmeye başlamıştı.

Türk ordusu Filistin Cephesi’nde iaşe sorunu ve nakil vasıtaları sorunu ve diğer lojistik eksiklikler nedeniyle savaşma iradesini tam olarak uygulama imkânından yoksun bulunuyordu. 1917 yılının ocak ayının ilk haftasında yaşanan şiddetli kum fırtınası iaşe nakliyatı için vazgeçilmez olan 700 devenin 600'ünün ölmesine vesile olmuş ve 100 devenin yetersizliği karşısında Almanların 506. ve 507'nci Oto Kollarından yararlanılması da benzin sorunu nedeni ile köklü bir çözüm olamamıştır. İngilizlerin ilerlemeleri karşısında 300'üncü Tayyare Bölüğü de Huç ve Birüssebi'de birer ileri kol bırakarak Ramle'ye intikal etmek zorunda kalmıştır. Bununla birlikte Alman bölükleri de yedek parça ve benzeri sıkıntılarla karşılamaya başlamıştır. Bununla birlikte uçuşlar programa uygun olarak yapılmaya çalışılmıştır (Kansu, 1971, s. 319; Keyüsk, 1952, s. 126, 127;). Bu tarihe kadar Alman bölüklerin Türk hava unsurlarına göre oldukça iyi imkâna sahip olduklarını, Türklerin savaşın başından beri daima iptidai şartlara katlanmak durumunda kaldıkları da bir başka gerçektir, (Yalçın, THHST 2013, s. 55).

1917 y1lında ordunun donatımında yaşanan sorunlar artmaya başlamıştır. 4'üncü Ordu Komutanlığı Başkumandanlık Vekâleti'nden uçak sayısının 2 katına çıkarılmasını, yine topçu takımlarının da bir kat artırılmasını isterken cephane sevkini de talep etmiştir. 1917 yılbaşı itibariyle acilen talep edilen benzin miktarı 20 tondur. Alman Paşa Tayyare Bölüklerinin bu dönemde önemli sıkıntılarının başında aşırı sıcak hava, tayyarelerin havadaki hararetten gerekli irtifayı alamaması ve kum firtınaları gelmektedir. İngilizler ocak ayı sonlarına doğru kuvvetlerini artırırken Türk ordusu da 3'üncü Süvari ve 16'nc1 Piyade Tümenlerince desteklenmiştir. Tellüşşeria - Şellale arasına $60 \mathrm{~cm}$. genişliğinde ve $20 \mathrm{~km}$. uzunluğunda dekovil hattı inşa edilmiştir. Diğer yollar tamirden geçirilmiş ve asker için gerekli her türlü cephane, mühimmat stokları oluşturulmuştur. Yeterli miktarda seyyar hastane oluşturulurken Birinci Kuvvei Seferiye 1917 yılı mart ayında Gazze - Birüssebi hattında mevzilenmiştir. 


\section{1. 1. 1. Birinci Gazze Muharebesi ve Hava Harekâtı}

Çanakkale Savaşlarında olduğu gibi Filistin Cephesi’nde de uçakların yapmış olduğu faaliyet göz dolduracak vasıftadır. Osmanlı Hava Kuvvetleri Osmanlı ordusunun; "gören gözü”, “duyan kulağı” ve "konuşan dili’" durumundadır. 25 Mart 1917 tarihli keşifte İngilizlerin bütün gücü ile ileri harekete başladıkları keşfedilir ve komuta katına bildirilir. Bu haberi oldukça erken alan komutanlar haberden memnun kalırlar (Göymen, 1969, s. 189 - 192). İngilizlerin Gazze'ye saldırısı 26 Mart 1917'de 2 piyade ve 1 atlı piyade tümeni ile Türk ordu birliklerine taarruz etmiştir. İngilizleri karşısında bulunan 3'üncü Süvari ve 16'ncı Piyade tümenlerinin karşı taarruzları ile İngiliz birlikleri geri atılmıştır. Gazze’yi alma ümidi kalmayan İngilizler şehirden çıkarılmış ancak her iki taraf birbiri üzerinde yoğun keşifler yapmışlardır. Türk tümenleri 3, 16 ve 53'üncü tümenler birleştirilerek Mürettep Kolordu oluşturulmuştur. Bu kolordunun numarası 22 olarak tespit edilmiştir. 28 Mart'ta Meşrafe bölgesinde, Tğm. Schultheiss ve Fritz tarafından İngiliz BE uçağını düşürülmesinin hemen ertesi haftasında, 6 Nisan 1917'de Üsteğmen Felmy ve Falke bir hava muharebesinde yine bir İngiliz uçağını kendi mevzileri önüne düşürmüştür (Kansu, 1971, s. 327; Keyüsk, 1952, s. 133 - 135 ). Filistin Cephesi, von Kress'in anılarına göre uçakların ve suyun en çok sıkıntılara sebep olduğu ve büyük sorunların yaşandığı bir cephedir (Yalçın, 2015, s. 286, 287). İngilizler suyu Nil Nehri'nden temin etmekteydi. Sina'da kuyulardan çıkarılan sular yetersiz ve acıydı (Miralay Muzaffer, 1934, s. 36). Sular kanallarla Port Sait ve Kantara'ya kadar getirilmekte ve burada içilir hâle gelmesi için tavsiye edilerek paralel 4 hat çelik borularla 24'er mil uzaklıkta yer alan El-Ariş'e getirilmekteydi. Borular, Süveyş Kanalı altından geçirilmiştir. Öyle ki, bu boruların siperlere kadar dağıtımının yapıldığı dikkate alındığında İngiliz ordusunun başarısını anlamak daha kolay olmaktadır. Osmanlı ordusu bu hatları tahrip etmek için hava gücünü kullanmaya karar verir ve boruların 1ssız oldukları yere inerek dinamitlerle imha edilmeye başlandı. İlk imha Felmy ve rasıdı Falke tarafından 10 Nisan 1917'e gerçekleştirilmiştir. Boru hatları demiryoluna paralel olduğundan İngilizlerin arızayı gidermesi pek zor olmamıştır (Kansu, 1971, s. 327; Keyüsk, 1952, s. 135 - 138; Göymen, 1969, s. 193). 


\section{1. 1. 2. İkinci Gazze Muharebesi ve Hava Harekâtı}

19 Nisan 1917 tarihinde başlayan saldırıda İngilizler 4 piyade, 1 süvari birliği, zırhlı otomobiller, muhtelif tipte 170 top, 4. 000 zehirli gaz mermisi ve 8 tankla saldırmıştır. Türk birliklerinin sert direnişi karşısında İngilizler yaklaşık 7. 000 ölü vererek ikinci defa geri çekilmişlerdir. Bu muharebelerde çatışmanın olduğu bir diğer alan gökyüzü olmuştur (Kansu, 1971, s. 327; Göymen, 1969, s. 194; Erickson, 2009, s. 154). Yeni bir silah sistemi olarak harp

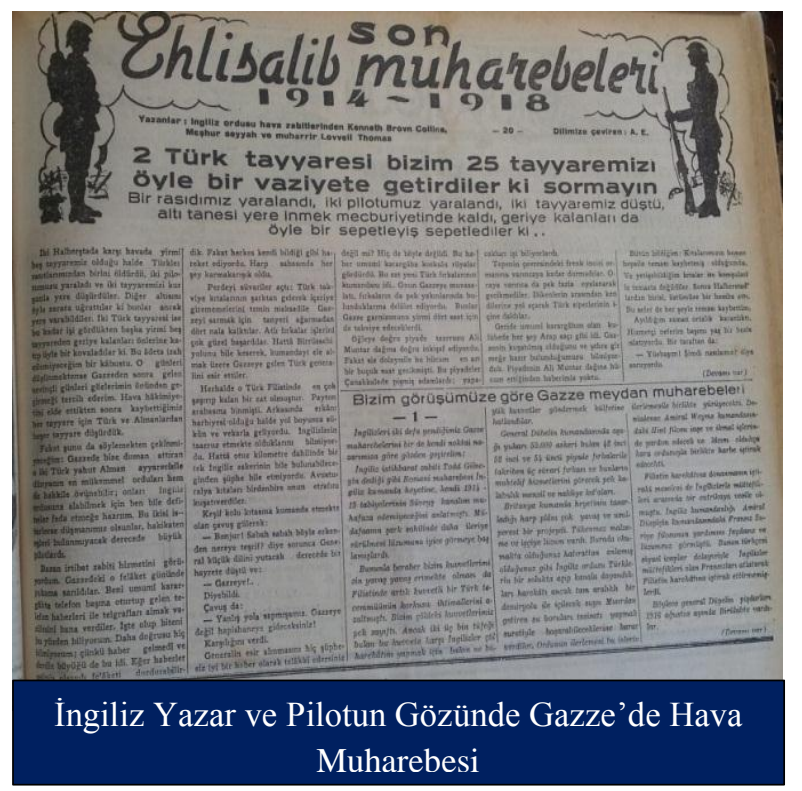
sahalarında yeni kullanılmaya başlayan tanklar beklenen performansı sağlamadı. Ya bozuldu ya da Türk topçu ateşinin isabetli ve başarılı ateşi ile imha edildi. İngilizler gaz kullanmalarına rağmen Türklerin cephe hattında çok etkili olmamıştır. Savaşın İngiliz komutanları Murray ve Dobell bu savaştaki başarısızlıkları sonucu İngiltere'ye gönderilmişlerdir. Türkler bu muharebede 11. 500.000 fişek, 30. 000 atım çeşitli top mermisi ile 617 el bombası kullanmıştır (Erickson, 2009, s. 155, 158, 159). Türk tayyare unsurları 18 - 19 Nisan 1917 tarihlerinde 19 sortide 38 saat uçarak İngilizler üzerine toplamda bir ton mühimmat atmışlar ve zayiatlar verdirmişlerdir (Göymen, 1969, s. 194, 195). İngilizler hava faaliyetinde halka yönelik olarak da yoğun bombardıman yaparak sivil halkı da cezalandırmışlardır. Örneğin 6 - 7 Mayıs 1917 tarihinde Ramle bombardımanında 23 kadın ve çocuk katledilirken 10 kişi de yaralanmıştır (Göymen, 1969, s. 196). Havcılığın yeni yeni toplum tarafından tanınmaya başladığı bu yıllar genelde kötü izler bırakmıştır. Şüphesiz bunda savaşların tam havacılığın doğduğu yıllara rast gelmesinin önemli etkisi olmuştur. $\mathrm{Bu}$ konuda birçok bakımdan İtalyanlar öncüdürler. Savaşlarda ilk uçağı kullanmak, bomba atmak, keşif yapmak bu kapsamdadır. İtalyanların bir diğer gerçekleştirdiği ilklerden birisi de bilinçli olarak hastaneleri bombalamaları olmuştur. Eskiden İngiliz ordusunda subay olarak görev yapan İngiliz Herbert Montagu, Trablusgarp'ta bulunduğu zaman İtalyanların kasıtlı hastane bombalamalarına şahit olmuş ve bu durumu çalışmış olduğu ajansa göndermiştir. Türklerin çekmiş olduğu hastane bayrağı ise hedefi daha iyi vurmak için değerlendirilmiştir (Kocatürk, 2011, s. 431). 
Ordu Komutanı Cemal Paşa harekâtı durdurdu ve önemli değerlendirmede bulundu. Paşa; Kanal yardımının yerli halka güvenilerek değil Anadolu'nun Türk askeri ile tayyarelik bir hava bölügü ile en az ikişer firkalı üçer kolordu, her kolorduda mükemmel bir istihkâm taburu, birer ağır topçu taburu, on buçukluk uzun, 15'lik obüs $21^{\prime}$ lik havan toplarına ihtiyaç olduğunu belirtmiştir (Miralay Muzaffer, 1934, s. 38). Filistin Cephesi'nde birçok olumsuzluklara karşın sabrı ve metaneti ile dayanaklılığı yerli yabancı birçok gözlemci tarafından dile getirilen Türk askeridir. Savaşın sonlarına doğru lojistik yeterlilik zora girdikçe ekmek, çorba ve zeytin ile savaşmak zorunda kalmışlardır (Arslan, 2015, s. 444 - 446). Harekât ile ilgili sonraki yıllarda birçok subay Alman ve Türk olmak üzere değerlendirme yapmıştır. Almanlar, görevin zorluğuna rağmen Almanya'nın bu sefere Osmanlı ordusunu yönlendirdiğini ve Cemal Paşa'nın mefkûresi ile de birleşen bir proje olduğuna değinmişlerdir. Ancak Almanya'nın gereken desteği de vermediğine sitem edilmiştir. Bununla birlikte Türklerin zor şartlarda Kanal'a dayanmasının İngilizleri telaşlandırdığını ve Mısır'ı savunmak için önemli bir kuvveti burada tutmak zorunda kaldıkları sonucuna temas etmişlerdir (Miralay Muzaffer, 1934, s. 39). Bu olumsuz yaklaşım her iki ülkenin personeli arasında da yaşanmıştır. Alman personel Türk subaya itaatte güçlükler yaşamakta ve hatta askerliğin en doğal kurallarından olan selamlaşmakta bile sorun olabilmekteydiler (Arslan, 2015, s. 446, 447).

\section{1. 1. 3. İkinci Gazze Muharebesi Sonrası Tarafların Hava Faaliyeti}

Türk hava kuvvetleri faaliyeti sürekli devam etmekte, su boruları imha edilmeye çalışılmaktaydı. Filistin Cephesi oldukça uzun bir sınırı içine aldığından bu alan üzerinde mevcut uçaklar ile etkin bir keşif faaliyeti ve kesintisiz hava hâkimiyeti kurmak özellikle İngilizlerin son zamanlarda artan uçak sayıları karşısında yetersiz kalmaktaydı. 4'üncü Ordu Komutanı Cemal Paşa 13 Temmuz 1917 tarihinde Başkumandanlık Vekâleti'ne yaptığı müracaatta bu duruma temas etmektedir. Cemal Paşa gönderdiği yazıda İngiliz ordusunun; Suriye ve Filistin'e yönelik bir harekât yapması ihtimali için İskenderun Limanı ve çevresinin haftada iki defa keşfinin yapılması gerekli olduğunu belirtmektedir. Mevcut 300'üncü Alman Paşa Tayyare Bölügünün miktarının iki katına çıkarılmasını ve anlaşıldığı kadarıyla Almanların Batı Cephesi nedeniyle gerekli desteği vermediklerinden Almanlar nezdinde girişimde bulunulmasını istemektedir.

İngiliz savunması 1917 sonlarına doğru süratle güçlendirilmeye devam etmiştir. Faaliyet sahası Osmanlı Hava Kuvvetleri tarafından devamlı keşfedilmekteydi. Yapılan tespitlere göre; demiryolu ve diğer menzil hattı üzerinde faaliyet artmakta, ordugâhlar 
çoğalmakta ve ağırlık merkezi cepheye doğru kaymakta, havadan gelecek saldırıya karşı sıkı önlemler alınmakta, İngilizler Osmanlı Hava Kuvvetlerine ağır kayıplar vermelerine rağmen Osmanlı ordusu ve hava savunmasının durumunu öğrenmek için aralıksız keşif yapmaya devam etmektedirler. İngilizlerin raporları bu süreci anlatmakta ve Türklerin savunması hakkında yeterli bilgiye sahip olduklarını göstermektedir (Keyüsk, 1952, s. 154, 155).

İngilizler, Türklere oldukça yaklaşmış bulunuyordu. Bazı yerlerde orduların birbirine olan yakınlıkları 100 - 200 metreye kadar yaklaşmış bulunuyordu. İngilizler Kuzeyde Akdeniz’e dayanmaktaydı. Türkler özellikle lojistik alanda önemli sorunlar yaşamakta ve tamamlanamayan demiryolları nedeniyle yeterli destek alınması istenilen seviyede olmuyordu (Göymen, 1969, s. 195).

\section{1. 1. 4. Yıldırım Ordularının Teşkili ve 1917 Yılı Faaliyeti}

Osmanlı ordusunun Filistin'de 1917 yılı başarılarına rağmen İngilizler Irak için de önemli bir tehdit unsuru olmaya devam etmekteydi. 11 Mart 1917'de Bağdat'in elden çıkmas1 büyük üzüntüye neden olmuştu. Osmanlı Ordusu Komuta Katı bu gelişme üzerine Bağdat'1 geri alarak İslam dünyasında oluşan yeisin telafisine ve bu önemli vatan toprağının İngilizlerden kurtarılmasına karar vermişti. Bu maksatla 7'nci Ordu teşkil edilmiştir. İngilizler ise Gazze'de aldıkları yenilgiler üzerine Sina cephesine ağırlık vermeye başlamışlardır. Türkler, Fırat Cephesi'ne ağırlık verirken İngilizler Filistin hudutlarında güç toplamaktaydılar. Alman kurmaylar da bu fikre destek verirken Sina Cephesi'nin takviye edilmemesi ve İngilizlerin orada sürekli güçlenmeleri ilerisi için önemli bir tehdide davetiye çıkarmaktaydı (Kansu, 1971, s. 319; Göymen, 1969, s. 199; Keyüsk, 1952, s. 155). Bağdat'ın kaybı ile buranın geri alınması için yapılan çalışmalarla Filistin Cephesi Irak Cephesi'nin gerisine düşmüştür. Bu konu tarihçiler tarafından tartışılmaktadır. Filistin Cephesi, bütün ehemmiyeti ile takviye edilerek korunabilseydi İngilizlerin buraya girmesi mümkün olmazdı ve mütarekede elde kalmış olurdu şeklinde bir düşünce ortaya atılmaktadır.

Bağdat'1 kurtarması için teşkil edilen birlikler bir süre sonra Yıldıım Ordusu adını almıştır. Yıldırım Ordusu, hava kuvvetleri bakımından da önemli destek unsuru ile güçlendirilmiş bulunuyordu (Kansu, 1971, s. 319). 
Alman Paşa Tayyare Bölükleri de Yıldırım Ordular Grubu emrinde olup üs bölgelerine gitmişlerdi. 300 ve 301'inci Tayyare Bölüğü Remle, 302'nci Tayyare Bölüğü El-Savafir,

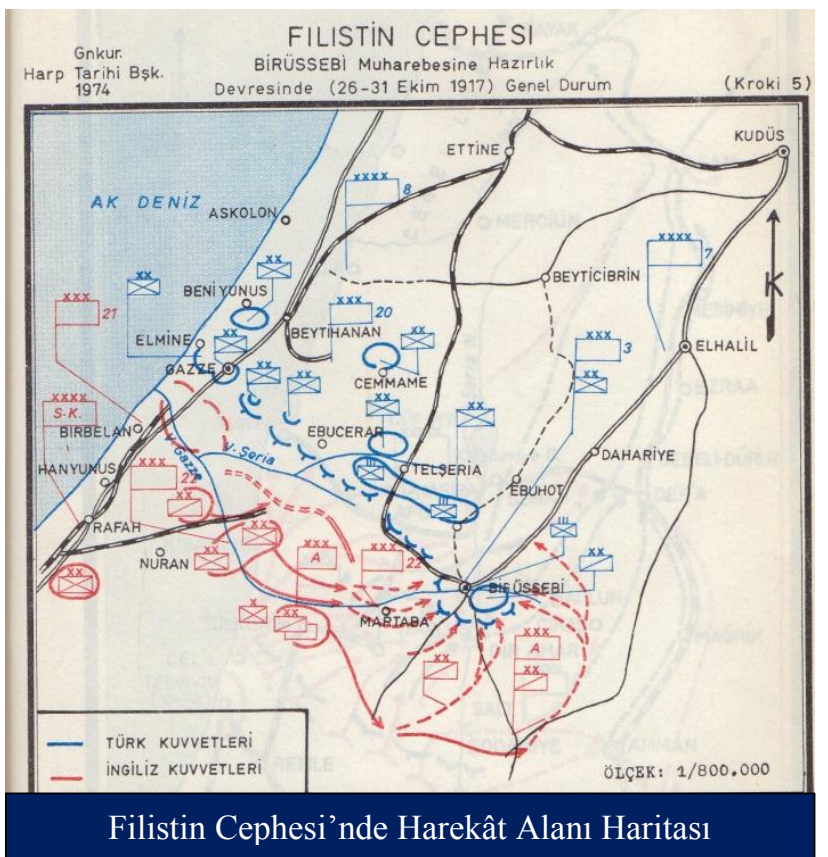
303'üncü Tayyare Bölüğü Ettine ve 304'üncü Tayyare Bölüğ̈ Arakelmenşir'de konuşlanmışlardır.

Y1ldirım Ordular Grubu'nun güneye yönelmesi İngiliz İstihbarat1 tarafindan en ince detayları ile ilgili birimlere rapor edildiğinden İngilizler güçlü Türk yığınağı yapılmadan Filistin'de taarruz yapmaya karar vermişlerdir. $\mathrm{Bu}$ maksatla bölgede bulunan hava unsurlarına da önemli takviyeler yaparlar. 15 Ekim 1917'de Spat tipi 4 uçağın Dirülbelah'ta Alman uçakları ile hava muharebelerine girmeleri ve bir Alman uçağını düşürmeleri İngilizlerin hava hâkimiyetinin ilk emaresi olmuştur (Keyüsk, 1952, s. 157 - 159). Von Kress'in anılarında İngilizlerin bu tarihte 25 uçakla harekât yapmaya başladıkları ve Remle'deki 300'üncü Paşa Tayyare Bölüğünün ise 6 uçakla görev yaptığı bilgisine yer verilmektedir (von Kress, 2007, s. 282 - 285).

İngilizler Filistin Cephesi’nde 1917 yılı ekim ayında aldatma yapmaya çalışmaktaydı. Yıldırım Orduları Komutanlığının beklentisi harekât alanının Gazze olacağı şeklindeydi. Oysa İngilizler gerçek harekâtı Birüssebi ve Tellişeria tarafından yapmak üzere yığınak yapmaktaydı. Birüssebi'nin güney ve güneybatısında Avusturyalı 6 piyade ve bir Anzak süvari tümeni bulunuyordu. Görüldüğü gibi Anzaklar ile yalnız Çanakkale Cephesi’nde değil Filistin Cephesi'nde Osmanlı ordusu ile karşılaşmıştır. Osmanlı Hava Kuvvetlerinin yapmış oldukları keşif, Osmanlı ordusunun beklentisine uymamaktaydı. Bu gelişme üzerine Osmanlı Ordusunun sol cenahına düşen Birüssebi ve Tellişeria üzerine 27 Ekim 1917 tarihinde kuvvetli bir keşif taarruzu yapılmıştır. İngilizler burada aldatma taktiklerini başarılı bir şekilde uygulamışlar, saldırılara gerekli yanıtı vermemişlerdir. Bunun üzerine Türk kara gücü, sol cenahın güçsüzlügüne hükmederek Yıldırım Ordular Grubunun önceki kanaatini teyit etmiştir. İşte asıl sorun da burada başlamıştır. Osmanlı hava unsurunun raporları dikkate alınmamıştır. Yine aynı 
gün İngiliz Hava Kuvvetleri, kendi cepheleri üzerinde güçlü baraj oluşturarak Türk uçaklarının keşif yapmasına kati surette izin vermemiştir. Bu tarih (27 Ekim 1917) aynı zamanda Üçüncü Gazze Muharebelerinin başlama tarihi olmuştur (Keyüsk, 1952, s. 160, 161).

\section{1. 1. 5. Üçüncü Gazze Muharebesi ve Hava Harekâtı}

1917 y1lı Nisan ayı sonunda İkinci Gazze Harekâtı sona ermiş ve taraflar yoğun bir hazırlık dönemine başlamışlardı. Bu süreç Ekim sonuna kadar devam etmiştir. Ancak bu süre içerisinde tarafların hava keşif ve faaliyeti devam etmiş ve ordular birbirlerinin hazırlıkları hakkında malumat almaya açılmışlardır. 4'üncü Ordu Komutanlığı, Filistin Cephesi'nde hava faaliyetinin artması nedeniyle Mayıs 1917'de Başkomutanlık Karargâhına gönderdiği raporunda 300’üncü Tayyare Bölüğü gibi yeni bölüklerin acilen gönderilmesini talep etmiştir (Göymen, 1969, s. 197).

Üçüncü Gazze Muharebesi eşitsizlikler muharebesi olmuştur. İngilizlerin 11. 500 adet topçu mühimmatına karşı Türk topçu bataryalarının mevcudu 300 adetten ibarettir. İngilizlerin buradaki başarısının muharebe başarısından Bir'üs sebi'ye yüklenmeleri ve Türklerin ise daha çok Gazze’ye yönelik bir hazırlıkları olması ile izahı yapılmaktadır. İngilizler manevra ve lojistik üstünlük kurarak direnme azmi olan Türkleri, kontrollü de olsa geri çekilmelerine sebebiyet vermişlerdir (Erickson, 2009, s. 195).

Türk tayyare bölükleri kademeli olarak Arakelmenşir'den Ettine'ye oradan da Ramle ve Tulükerim'e çekilirler. İngilizler sayısal ve teknik olarak güçlü olan uçakları ile Türk kıtaatları üzerine taarruz etmektedir. Bu durum ise Türk birliklerinin çekilirken düzenin bozulmasına neden olmaktaydı. İngiliz tayyare birlikleri kara unsurlarına paralel ilerlemekte ve Türklerin boşalttı̆̆ı meydanları da kullanmaktaydılar. 30 Kasım 1917'de 113'üncü Tayyare Filosu Ramle'ye, 14'üncü Tayyare Filosu ise Ramle - Kudüs Demiryolu'nun birleştiği mevkie konuşlanmıştır. $\mathrm{Bu}$ süre zarfında Türk ordusu yeniden bir savunma hattı kurarak İngilizleri durdurmayı başarmıştır (Keyüsk, 1952, s. 164).

1917 yılında Filistin Cephesi'nde faaliyet gösteren 4'üncü Tayyare Bölüğü faaliyeti Doğu Akdeniz merkezli devam etmiştir. Kıbrıs'a yönelik Silifke'den keşif faaliyeti sürdürülmüştür. O dönemin uçaklarının kabiliyeti bakımından Kıbrıs'a gidip gelmek önemli bir performansı gerektirmekteydi. Uçakların en az 2 saat havada kalması ve $200 \mathrm{~km}$. den fazla mesafeyi kat etmesi gerekiyordu. Üstelik deniz üzerinde yapılan uçuşun kendine has zorlukları bulunmaktaydı. Kaza anında yapılabilecek şeyler de oldukça sınırlıydı. Bu nedenle Silifke'de 
bir deniz tayyare bölüğü kurulması (Kansu, 1971, s. 25, 320), 4'üncü Ordu Komutanlığ1 tarafından Başkomutanlığa teklif edilmiştir. Başkomutanlık Vekâleti, verdiği cevapta Almanya'dan 24 deniz uçağı talep edilmesine rağmen henüz teslim alınmış uçak bulunmadığ cevabı verildiğinden görev yine kara uçaklarına düşmüştür. Ancak Türk havacılarının birçok konuda önemli sıkıntıları bulunuyordu. Teknik ekip yetersiz ve alanında otoriter değildi, malzeme sorunu daima önemli bir problemdi. Havacılar mesleğe yeni intisap etmişlerdi, havacılığın kurumsal kültürü henüz tam oluşamamıştı ve havacılık sektör olarak ilk yıllarını yaşamaktaydı. Belki de en önemli bir diğer sorun, emir - komuta zincirinde yaşanan kırılma ve belirsizliklerdi. Emir verme salahiyeti Umuru Havaiye Müfettişliğine aitti. Oysa görev yaptıkları birliklerin komutanlarının da emir ve görev taleplerine uymak durumundaydılar. Birçok amirlerinin olması ayrı bir sorun olarak daima gündemde kalmıştır. Bazı zamanlar hava bölük komutanları Hava Müfettişliğine bağlı oldukları bölge komutanlıklarının üzerlerinde ne gibi sevk ve idare yetkisi olduğunu sormakta ve yaşanan tatsız olayları iletmekteydiler. Kaldı ki, 4'üncü Ordu Komutanı Cemal Paşa havacılara oldukça yakın davranmakta ve ihtiyaçlarını karşılamaya önem vermekteydi (Kansu, 1971, s. 254; Keyüsk, 1952, s. 181, 182).

Kudüs'ün düşüşü İtilaf güçleri başkentlerinde olduğu gibi Almanya'da da büyük bir sevinç duyulmasına vesile olmuştur. Özellikle müttefik ülkelerin başkentlerindeki büyük şenlikler ve kutlamalar bu tarihlerde kutlamaların yapıldığı başkentlerde bulunan Türkler için şaşırtıcı ve dikkat çekici bulunmuştur. Aslında bu olağan bir durumdu. Savaşta müttefik olmalarına rağmen Almanların ve Osmanlıların birbirine şüphe ile baktıkları genel bir kabul hâline gelmiştir. Subay anılarında bu durum açıkça yazılmaktadır (Von Kressenstein, 2007, s. 126, 127). Nitekim Enver Paşa'nın Kafkas İslam Ordusunun ileri harekâtından rahatsızlı̆̆ı açıkça belli olan Almanların tepkisini de dikkate alarak komutanlarına emir verse bile Bakü ele geçirilinceye kadar emri almamış gibi hareket ediniz direktifi (Yel, 2014, Semp.) üzerinde düşünülmesi gereken ve Türk ordusunun en üst makamında da müttefiklerle farklı görüşler içinde olunduğunu göstermektedir.

\section{1. Savaşın Son Yılında Filistin Cephesinde Hava Harekâtı}

Avrupa'da 1918 başında dengeler daha açık olarak İtilaf güçleri lehine değişmeye başlamıştır. 62. 000 asker ile Amerika'nın Avrupa'da görünmesi Almanların işini daha da zora sokmaktaydı. Alman ordusunun başı Hindenburg ile yardımcısı Ludendorff'un İngilizleri ve Fransızları bölerek ortadan kaldırma planları ilk başlarda başarılı şekilde ilerlese de sonuca ulaşmamıştır (Kansu, 1971, s. 345, 346). 


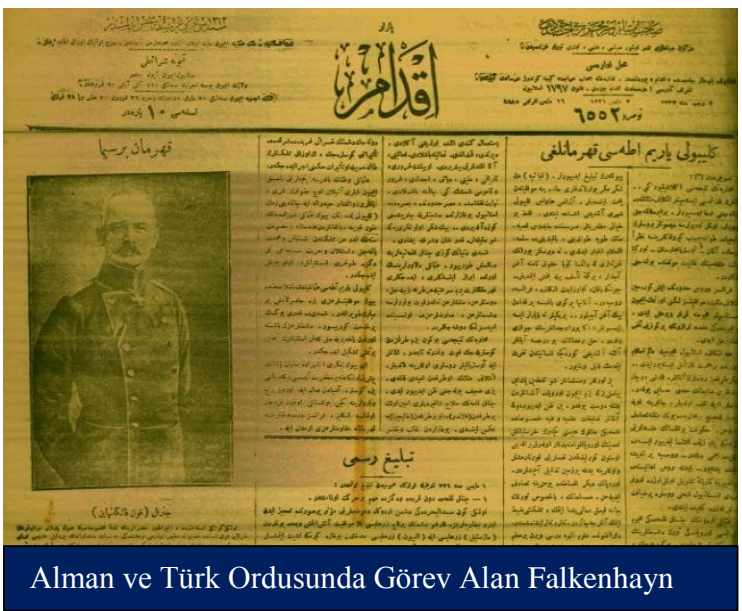

Alman ve Türk Ordusunda Görev Alan Falkenhayn

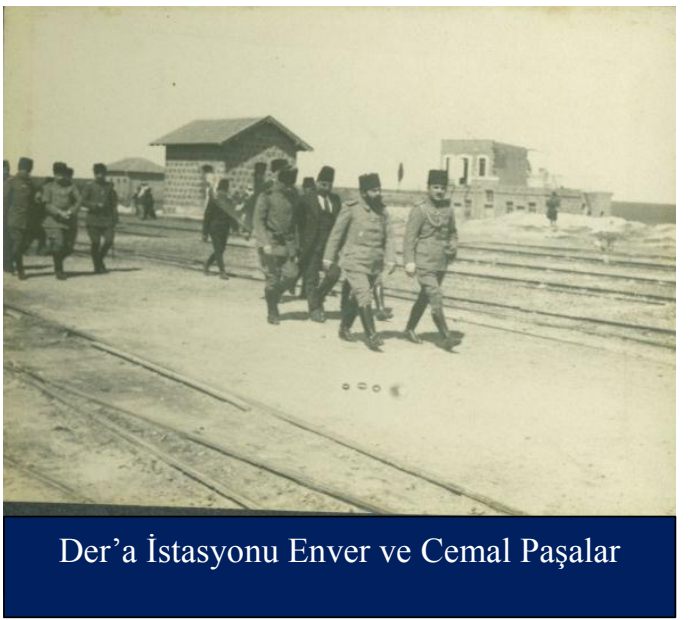

toplamışlardı. Birinci Fransız tümeni 16 Mayıs - 10 Kasım 1918 tarihleri arasında 637 uçak düşürmüştür. Aynı birlik 125 Drachen Sabit Balonu'nu tahrip etmiştir. Cephede hava muharebeleri oldukça kalabalık uçaklarla yapılmaya başlanmıştır. 25 Mart 1918'de yapılan bir hava muharebesinde 70 uçak hava muharebesi yapmış, 14 İngiliz, 4 Alman uçağı zayi olmuştur. Yine bir başka hava muharebesinde 21 Nisan 1918 'de 80 uçak düşüren Alman pilot Manfred Von Richthofen, İngiliz filo komutanı Brown tarafindan düşürülmüştür.

23 Nisan 1918 Kemmel Taarruzu'na Almanlar 200 uçakla katılmışlardır. Mayıs ayında İngilizler 130 Alman uçağını düşürmüştür. Makedonya Cephesi'nde daha çok Fransız hava gücü Bulgarlara karşı 16 ve 32'li uçaklarla saldırarak büyük zayiat verdirmişler. Bu savaş hava endüstrisinin gelişmesine şahit olmuştur. Savaş süresince 200. 000 uçak ve 250. 000 uçak motoru üretilmiştir. Bu üretimin 1/4’ü Almanlara aittir. Savaşta en çok kayb1 ise İngilizler vermiştir. 9. 478 ölü, kayıp ve esir, 7. 245 yaralı verilmiştir. Oysa Fransızlar 1. 815 ölü veya kayıpla 2. 840 yaralı vermiştir. Karşı İttifakta yer alan Almanya ise 7. 750 ölü ve 6. 155 yaralı vermiştir (Kansu, 1971, s. 347 - 351; Yalçın, 2004, s. 96, 108; Yalçın, AAM, 2010, s. 3 - 5). Türk havacılardan Ali Rıza ve Rasıtı Orhan ile Asb. Cemal Turgutlu ve Tğm. Hasan Basri birer uçak düşürmüşledir (Kansu, 1971, s. 350 - 353; Yalçın, THHST 2013, s. 47). 16 Şubat 1918'de 
bu Suriye ve Arabistan Ordusu lağv edilerek 4'üncü Ordu adında yeni bir ordu tekrar teşkil edilmişstir.

Daha önce Almanya'da Genelkurmay Başkanı olan takiben Türkiye'ye gelen ve Yıldırım Orduları Komutanlığını yürüten Erich von Falkenhayn ${ }^{5}$ Yıldırım Orduları Grubunun komutasını 26 Şubat 1918'de Liman Von Sanders'e bırakmıştır. Osmanlı Paşası olarak görev yapan Sanders teşkilatta yeniden düzenlemeler yapmıştır. Yeniden teşkil edilen 4'üncü Ordu bağlısı birlikler; merkezi Dera'da bulunan 8'inci Kolordu, 1'inci Maan, 2'nci Tebük Kuvvei Mürettebeleri, 21'inci Asir Tümeni, 7'nci Yemen Kolordusu ile Hicaz Kuvvei Seferiyesi’nden oluşmaktaydı. İkinci Ordu K.lığı namında bir ordu daha oluşturulmuştur. Bu ordu Karargâhları Adana'da bulunan 12. ve 15'inci Kolordu Komutanlıklarından teşkil edilmiştir. 2'nci Ordunun merkezi Halep'te bulunacaktı. Bu yapı ile Akdeniz'den İran'a kadar olan bölge Yıldırım Orduları Grubu'na verilmiş oluyordu. Bu alan; Musul, Halep, Adana, Suriye, Beyrut, Hicaz ve Yemen İlleri, Cebeli Lübnan Bağımsız Mutasarrıflığı ile 2, 4, 6, 7 ve 8'inci orduları kapsamaktaydı (Kansu, 1971, s. 390; Göymen, 1969, s. 238; Keyüsk, 1952, s. 378, 383; N. Koçoğlu Töp., 2007, s. 3, 6). Ancak bu ordulardan 2'nci ve 6'ncı Ordular Irak ve Suriye'nin güvenliği için görevlendirilirken 4'üncü, 7'nci ve 8'inci ordular denizden Şeria'ya ve Şeria'nın doğusuna bakacaktı.

1918 yılında İzmir, Şam ve Musul'da birer uçuş okulu açılması planlanmışsa da şartlar buna müsaade etmemiştir. Yine düşürülen uçaklardan bir müze kurulması için uçak enkazları toplattırılmıştır. "Vakayi ve Terakkiyat-ı Havaiye Mecmuası" olarak çıkan dergi 17'nci sayısını çıkarmıştır. ATASE Arşiv Kataloglarından yapılan incelemede mecmuaların bütün hava birliklerine dağıtıldığına dair özetler sıklıkla yer almaktadır. Bu yıl içinde önemli bir değişiklik ise Sultan Vahdettin'in Başkomutanlığı bizzat üzerine alması ile Enver Paşa'nın konumunun Erkan-1 Harbiye Reisi olarak yeniden düzenlenmesidir. Enver'in yetkilerinde bir değişiklik olmamıştır. Bu yılsonuna kadar zorunlu olarak Türk cephelerine indirilen veya inmek zorunda kalan itilaf güçleri uçaklarından 57 personel enterne edilmiştir (Kansu, 1971, s. 354).

Liman von Sanders'in Yıldırım Orduları Grubu Komutanı olmasıyla birlikte teşkilatta yeni değişiklikler yapılmıştır. 2'nci ve 6'ncı Ordular gruptan ayrılmıştır. Karargâh Nasra'da bulunmaktaydı. Yeni durumda da denizden Şeria'ya kadar olan bölge 7'nci ve 8'inci ordulara

\footnotetext{
5 İkdam, 12 Mayıs 1915
} 
verilirken Şeria'nın doğusu 4'üncü ordu komutanlığı kontrolüne verilmiştir (Keyüsk, 1952, s. 391)

4 Ocak 1918 tarihinde 12 - 14 İngiliz uçağı toplu hâlde Türk hava meydanı Cenin'e taarruz ederler. Yerden açılan hava savunma sistemleri ateşi ve havadan yapılan taarruzlarla İngilizlere ait bir av ve bombardıman tayyaresi düşürülmüştür. $\mathrm{Bu}$ harekâtta esir edilen Avustralya hava filosu mensubu Üsteğmen Parkenson, ifadesinde önemli bilgiler vermiştir. İfadesinde 300'üncü Paşa Bölügünde görev yaparken bir zorunlu iniş sonrası esir edilen Üsteğmen Ditmar'a oldukça saygı duyulduğu, on dakika uçacak kadar yakıt verildiğini belirtmiştir. Yine Parkenson ifadesinde İngilizlerin Filistin'de 5 Numaralı Tayyare Grubu, İsmailiye'de 21 Numaralı tayyare müfrezesi ve Ebukır'da 20 Numaralı tayyare müfrezesi konuşlandığı bilgisini vermiştir (Kansu, 1971, s. 398; Keyüsk, 1952, s. 382).

1918 yılı Ocak ayında 4’üncü Tayyare Bölüğünün Medine’ye gönderilmesi planlanmış, bölük personelinden Gayrimüslimler değiştirilerek yerine Türk personel atanmıştır. Bu kapsamda Pilot Susin ile Maltepeli Fehmi’nin yerleri değiştirilmiştir. Ocak ayının son gününde yapılan düzenleme ile 4'üncü bölügün de 305'inci (yeni 14'üncü Bölük) Bölük emrine verilmesi kararlaştırılmıştır. İngilizlerin 31 Mart 1918 tarihinde Amman’1 işgal etmeleri gündeme geldiğinde Türk uçaklarının 305'inci Bölük karargâhında toplanmaları istenmiştir. Toplanma süresinde bir Türk uçağı havada 2 İngiliz uçağı ile karşılaşır. Hava muharebesi esmasında Türk uçağının makineli tüfeği arıza yapar ve Svl. Pilot Behçet ile Rasıt Tğm. Sıtkı Tanman yere inmek zorunda kalırlar. Havacı personel Dindali Kabilesinin eline geçerler ve bu esnada Kolordu Komutanı Albay Fuat Erden'in treninin istasyona gelmesi ile hayatları kurtulur. İngiliz birlikleri Amman içlerine kadar ilerlemiş ve burada bulunan Hava Meydanı da işgal edilmek üzereyken havacı personel de mevziiye girerek piyade savaşına iştirak etmiştir (Göymen, 1969, s. 242; Keyüsk, 1952, s. 393 - 398).

27 Nisan 1918 tarih ve 547 sayılı Tayyare Kıtaat Komutanlığının haftalık raporunda İngiliz birlikleri ile ilgili keşiflerden elde edilen son bilgiler verilmektedir. Rapora göre İngilizler siper kazma faaliyetini önceden olduğu gibi sürdürmektedir. Bu faaliyet 7'nci Ordu gerisinde ve 4'üncü Ordu Cephesi'nde devam etmektedir. Elmüsallabe mevkiinde yeni ve kısa siperler teşkil edilirken burada İngiliz birlikleri keşfedilmiştir. İngilizler tarafından Şeria'da 6 adet köprünün doğusunda yeni bir köprübaşı oluşturulmuştur. İngilizler cephedeki birliklerini yavaş yavaş gerilere alırken gerideki araziyi takviye ettikleri keşfi yapılmıştır. Yine yapılan keşiflerde İngilizlerin cephe önünden kademeli olarak çekilirken cephe derinliklerinde 
$584^{* \text { TAED }} 55$

Osman YALÇIN

birliklerini bir yerden diğer yere kaydırdıkları, cephe yolları üzerinde bulunan yürüyüş yollarındaki hareketlikten anlaşılmıştır (Keyüsk, 1952, s. 402, 403).

Filistin Cephesi'nde orduların faaliyeti mayıs ayından itibaren bir taarruz hazırlığına doğru yönelmiştir. Osmanlı ordusu muharebeden çıkan birliklerini toparlayıp teşkil ve tanzim ederken İngilizler de kendi mevzilerini kuvvetlendirmekte ve cephelerini Türk ordusu aleyhine genişletmekteydiler. Asilerin Osmanlı ordusu karşısındaki tazyiki de giderek şiddetlenmekteydi. Mayıs ayı itibariyle İngiliz hava kuvvetleri her zamankinden daha fazla havaya hâkim durumdaydı. Osmanlı tayyare bölüklerine yeni uçakların sevki olmamakta ve Paşa Bölükleri de dâhil olmak üzere kırılan ve kal edilen uçakların üzerinde çalışarak faal ettikleri uçakları yeniden uçuşa vermekteydiler. 1918 yılı mayıs ayında da Riyak Parkı'nda bulunan 240 BG. ye haiz Mercedes motoruyla mücehhez 4XRumpler uçağı hazırlanmış ve bunlardan biri 303'üncü, üçü 304'üncü bölüğe verilmiştir. Ne var ki, İngilizlerin elinde bulunan Bristol ve S.E. 5 uçakları karşısında Rumpler uçakları yetersiz kalmaktaydı. Ancak süratlerinin Bristol'den yüksek olması bir avantajdı. Türk Tayyare bölüklerinin en önemli sorunlarından biri de hava savunma için yeterli silah sistemine sahip olunmamasıyd. Tayyare meydanlarını birkaç makineli tüfekle korumak mümkün olamıyordu. Son zamanlarda bazı yerlere yerleştirilen top tabyaları da İngiliz uçaklarına mani olamamaktaydı. İngiliz uçakları hangarların üzerine kadar gelip taarruzda bulunmaktaydılar (Keyüsk, 1952, s. 406). Türk uçakları haziranın ilk haftasında İngiliz hatlarına 100 sorti yapma yeteneğine sahipken, Ağustos ayında bu rakam 80 sortiye gerilemiştir.

1918 yılı temmuz ayında 14'üncü Tayyare Bölüğünün uçak ihtiyacı artmış durumdaydı ve yeni uçak sevk edilmemekteydi. Bölük imkânları ile kullanılmayan 2 uçağın parçaları bir araya getirilerek yeni bir uçak elde edilmiştir (Kansu, 1971, s. 400). Amman'da Osmanlı Hava Kuvvetlerinin yığınak yaptığını öğrenen İngiliz Hava Kuvvetlerinin bölge üzerindeki tarassudu (gözetleme) artmıştır. Burada özellikle 305'inci Tayyare Paşa Bölüğü ile 3, 4 ve 14'üncü Tayyare Bölügünün ve 302'nci Paşa Bölüğüne ait bir müfrezenin 20 ve 19 uçaklık paketler hâlinde İngilizlere saldırmaları savaşın son yılında göz doldurucu gelişmelerden olmuştur (Kansu, 1971, s. 399).

Alman uçaklarından müteşekkil 6 uçaklık bir filo bölgeye av önleme filosu olarak gelmiştir. Bu uçaklardan beklenen fayda sağlanamamış, bir uçuş esnasında 2 İngiliz keşif tayyaresine karşı etkisiz kalmış ve iniş esnasında da 3 tanesi kırım geçirdiğinden katkıları olmayacağı gerekçesiyle iade edilmişlerdir. Türk Hava Bölüklerinden 3, 4 ve 14'üncü Bölükler geçen her gün güçlerini kaybetmeye başlamışlardır. Eylül 1918 başında Yıldırım Orduları 
Grubu emrinde uçuşa müsait uçak sayısı 8 keşif ve 5 av tayyaresinden ibarettir. İngilizler \% 90 hava hâkimiyetini ele geçirmiştir.

19 Eylül 1918 tarihinde İngilizlerin büyük taarruzu başladığında imkânsızlıklar ile mücadele eden bir Osmanlı ordu sistemi bulunuyordu. Bu savaş Türk tayyarecileri için o kadar yıkıcı olmuştur ki, Nasıra ve diğer yerlerdeki tayyareci mezarlığında 47 pilot ve rasıdın ismi yer almaktaydı. Bu bakımdan Filistin Cephesi Türk hava varlığının en önemli unsuru olan uçuş personelinin \% 75'ini kaybetmesi ile neticelenmiştir (Kansu, 1971, s. 399; Keyüsk, 1952, s. 407 - 409; Guhr, 2007, s. 199 - 202). Alan Palmer eserinde Eylül saldırılarını Türk ordusunun kaybetmesinin en önemli sebebi olarak İngiliz uçaklarını yazmaktadır. Palmer'e göre Faysal'ın, Dera kuzeyinde demiryollarını kesmesi büyük katkı sağlamıştır. Türkler ise göz dolduracak bir mücadele sergilemişlerdir (Palmer, s. 381).

Başkomutan Vekili Enver Paşa, 6 Ağustos 1918 tarih ve 1.Şubenin 6769 / 7651 sayılı tamimi ile düşman askerlerini kendi hükümetlerine karşı harekete geçirecek veya ilticaya sevk edecek beyannamelerin uçaklarla atılmasını kati surette yasaklamıştır. Öyle ki, 22 Ağustos 1918 tarih ve 7177 / 8848 sayılı emir ile de beyannamelerin asiler üzerine atılmasını ancak asilerin bulunduğu mevkide düşman askeri birliği varsa atılmamasını istemiştir (Keyüsk, 1952, s. 415, 416).

İngiliz hava kuvvetleri Temmuz ayından itibaren Türk mevzileri ve hava meydanları üzerindeki baskılarını artırmıştır. $\mathrm{Bu}$ mevsimde sıcaklar 72 dereceye kadar yükselmiştir. 14'üncü Tayyare Bölüğü yeni aldığı 2 tayyare dâhil 4 tayyare ile faaliyet gösterebilmiş, bölük envanterinde yer alan 5 uçak değişik nedenlerle elden çıkmıştır. İngiliz uçaklarının taarruzu irtifayı bile dikkate alınmadan Osmanlı hava unsurları üzerinde yoğunlaşmıştır. 16 - 25 Temmuz tarihleri arasında 15 İngiliz uçağı, Amman İstasyonu ve tayyare meydanına taarruz etmiş̧tir ve 80 bomba atmışlar. İngilizlerin taarruzu Ağustos ayında da 20 uçaktan oluşan filo şeklinde sürmüştür (Göymen, 1969, s. 249).

İngilizlerin büyük gayretlerle hazırlandıkları "Eylül taarruzu" Osmanlı ordusu bakımından oldukça sıkıntılı bir dönemdi. Filistin Cephesi'nin sorumlusu olan Yıldırım Orduları Grubu Komutanlığı bağlısı 4, 7 ve 8'inci orduların toplam kılıç ve tüfek gücü 23 . 000 'in biraz üzerindeydi. Cephe genişliği ise yaklaşık $100 \mathrm{~km}$. uzunluğundaydı. Oysa İngilizlerin 21. 000 kılıç, 57. 000 tüfek olmak üzere 78. 000 muharip güç ile 540 topu 
bulunuyordu (Kansu, 1971, s. 390; Keyüsk, 1952, s. 444). Hava gücü ise uçak olarak artık yüzlü rakamlarla ifade edilmekteydi.

Birinci Dünya Savaşı'nın sonunu getiren başarılı itilaf gücü taarruz gücünü ABD'nin taze güçlerle ve yeni silah sistemleri ile muharebeye verdiği destekten almıştır (Göymen, 1969, s. 252). Birinci Dünya Savaşı'nın son yılında Osmanlı hemen her cephede kaybetmeye başlamıştır. Ancak en önemli gelişmeler Filistin Cephesi’nde yaşanmaktadır. Zira 1918 yılının başlarında İttifak güçlerinin durumu gittikçe zorlaşmış ve savaşın kaybedileceği endişeleri baş göstermiştir. Birinci Cihan Harbi’nden havacılık alanında yeterli derslerin çıkarıldığını bütün devletler açısından olduğu gibi uzun vadede Türkiye için de söylemek zordur. Her şeye rağmen savaş stratejisi açısından yapılan incelemeler bugün de önemini korumaktadır. İngiliz tarihçisi ve askerî düşünürü Sır Liddell Hart, "Birinci Dünya Harbi Tarihi” isimli kitabında Filistin Cephesi’nde Türk ordularının yenilmesinde, İngiliz Hava Kuvvetlerinin çok etkin bir rol oynadığını yazıyor. Hart, savaşın değerlendirmesini şöyle yapıyor: "19 Eylül'de yapılması planlanan genel taarruzda bir riske girilmemesi için her şeyden önce Türk komutanlığının sağır, dilsiz ve kör duruma getirilmesi gerekiyordu. İngiliz orduları Komutanı General Allenby'nin bu amaçla kullanabileceği nispeten yeni ve alışılmamış iki vasıtası vardı: Uçaklar ve yerli Araplar." (Sarp, 1986, s.96).

Albay Lawrence'in komutası altında yerli Araplar (Altın, 2014, s. 211) Hicaz Demiryolu hattı boyunca Türkleri devamlı olarak taciz edip zor durumlara sokuyorlardı. Oysa 1 Eylül 1900 tarihinde bütün İslam dünyasının bağışlarıyla ve büyük ümitlerle yapılmaya başlayan bu hat (Tekin, 2009, s. 145) şimdilerde Türk ordusuna zarar vermek için kullanılmakta, Türk ordusu ise açık tutmak için büyük bir gayretle mücadele etmektedir. Asilerin, İngiliz birliklerinin son ve kesin darbesine en büyük yardımı yapmalarının sırası gelmişti. 16 ve 17 Eylül günleri, çölün kumları arasından çıkan hayaletler gibi Deraa Şehrinin kuzey, güney ve batısında demiryollarını havaya uçurdular. Bu suretle Türklerin ikmal hatları kesilmiş oluyordu. 
19 Eylül 1918'de İngiliz ordusu, Osmanlı ordusuna Filistin Cephesi’nde sekiz kat kuvvetle saldırmıştır. Liman Von Sanders Paşa, Mustafa Kemal Paşa’yı IV. ve VIII. Orduları düzenleyerek yeniden bir savunma hattı kurmakla görevlendirmiştir. Kurulan yeni savunma hattı ile Halep'e kadar çekilme emri verilmiştir (Tunçay - Akşin, 1990, s. 51). Mustafa Kemal'in komutanı olduğu Nablus'taydı. Bu orduya bağlı 2 kolordunun komutanları ileride Millî Mücadelede beraber çalışacakları Albay Ali Fuat (Cebesoy) ile Albay İsmet (İnönü) Beylerdir (Tulga, 1980, 26). IV. Ordu artıkları VII. Ordu emrine verilmiştir. İngilizlerle 13

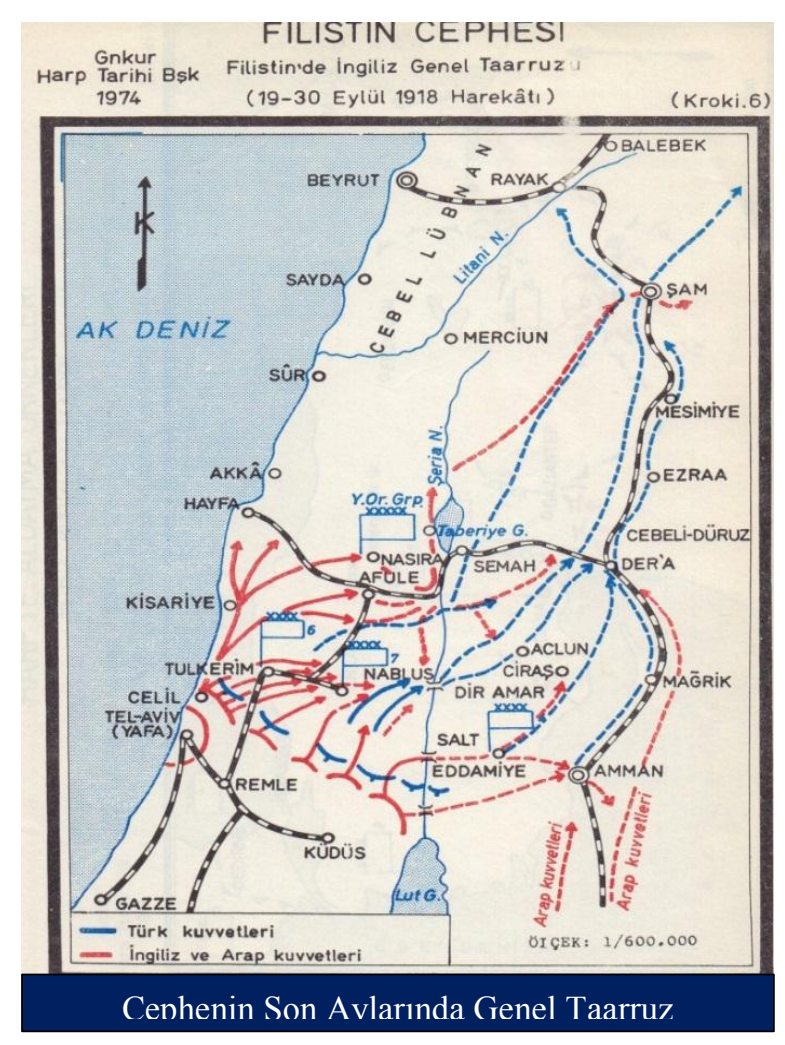

Ekim 1918'de Halep'in kuzeyinde Katma'da çatışmaya girilmiş, bu son ciddi çatışma ile İngilizlerin Anadolu kapılarında durdurulması başarılmıştır. Filistin Cephesi'nde yaşananlar havacılığın savaşlardaki etkisi ve sonuçları bakımından oldukça önemlidir. Mustafa Kemal Paşa, cephede harekâtın sonucunu belirleyen önemli unsurun uçaklar olduğuna bir kere daha şahit olmuştur. Burada yaşananların ileride havacıllğga önem vermesini perçinleştiren önemli gelişmeler olduğu değerlendirilmektedir.

Liman von Sanders'in komutanlığ da başarısız bir şekilde sonuçlanmıştır. Sanders Ordunun Suriye ve Filistin'den çekilmesine inanıyordu. Ancak bunu kendisinin yapmasının mümkün olmayacağını memleketin asıl sahibi bir Türk subayın bu yetkiyi kullanmasına inanmaktaydı. Yetkiyi Mustafa Kemal Paşa'ya bırakır ve takiben ülkesine dönmeye çalışır (Tulga, 1980, s. 28). İngiliz raporuna göre, İngiliz Hava Kuvvetlerinin yardımı ise iki safhadan meydana geliyordu. Birincisi, aralıksız devam eden hava savaşları ve meydanlara taarruzlar sonunda Osmanlı uçakları havalardan tamamen silinir. Bu hava mücadelesi o kadar ileriye götürülür ki, sonunda Osmanlı meydanları üzerinde bekleyen uçaklar, bir tek Türk uçağının yerden kesilmesine müsaade etmediler. Böylece, hazırlık safhasında Türklerin havadaki gözü köreltilmiş oluyordu. 
İkincisi, taarruz planının uygulamaya konulacağı gün geldiğinde İngiliz Hava Kuvvetleri Türklerin komuta ve kontrol sistemini sağır ve dilsiz hâle getirdi. Daha sonra Avustralya'ya yaptığı tarihi uçuşla ün yapan Pilot Ross Smith, Afule İstasyonu'ndaki ana telefon ve telgraf merkezini gece bombardımanıyla tahrip etmek suretiyle İngilizlerin zaferine yardımcı oldu. Ayrıca Türklerin Nablus ve Tul Keram'daki iki ordu karargâhı da bombalandı. Bunlardan Tul Keram'da karargâhla beraber telgraf ve telefon hatları o kadar başarıyla tahrip edildi ki Türk ordu karargâhının tümenleriyle irtibatı tamamen kesildi.

Havalardaki diğer bir faaliyet de, belki bomba atmak kadar etkili olan propaganda broşürlerinin atılmasıydı. Bu bol resimli broşürlerde esir kamplarındaki Türk askerlerinin konforlu yaşantılarına ait fotoğraflar yer alıyordu. Elbette bu fotoğraflar, yarı aç ve dayanma gücü gün geçtikçe azalan askerlerin kafasında, üseraya özenti oluşturmaktaydı. 19 Eylül 1918 günü sabaha karşı cephe boyunca topçunun başlattığı yoğun ateşi takiben taarruza geçen birlikler fazla bir direnmeyle karşılaşmadan siperleri geçtiler. Geri çekilme esnasında Mesudiye geçidinde sıkışan 8 . Türk ordusuna ait birlikler üzerine bomba ve makineli tüfeklerle taarruz eden İngiliz uçakları bu birliklere büyük kayıplar verdirdiler.

26 Ekim 1918 tarihine kadar esir asker sayısı 75.000 kişidir. Savaş süresince 202.000 esirin kisa zaman içerisinde burada verilmiş olması büyük bir kayıptır (Yalçın, 2015, s. 289; Taşkıran, 2011, s.40, 60 - 64; Westwell, 2014, s. 236, 237). Tabii bu kısa süre içerisinde havadan gelen tehditlerle şehit sayısı 30.000 kişi civarındadır. Filistin Cephesinin çöküşü bir hazin hikâyedir. 3'üncü Süvari tümeni 8'inci Alay 3'üncü Bölük K.lığının teslim olma hikâyesi burada anekdot olarak anlatılmıştır. Bölük Komutanı, tümenin durumunu anlamak ve tazyik eden İngilizlerin tavrının sonuçlarını anlamak için gözcü gönderir. Bu gözcüler tümenin esir olduğu haberini getirirler. 3'üncü Bölük komutanı bu durum üzerine birliğine hitap eder. Yıllardır beraber savaştıklarını ancak tümenin bir mecburiyet ile geriye dönüşü olmadığından İngilizlere esir olduğunu söyler. Kendilerinin de gidip teslim olmalarını ve haklarını helal etmelerini ister. Ancak bölük kendisi ile gerektiğinde ölümü göze alarak birlikte hareket etme kararı alır (Güralp, 1941, s. 28). Bu dönemde bazı aşiret liderleri İngilizlerin bahşettiği altın ve liderlik verme taahhüdü sonucunda halk üzerinde baskı kurarak kendi şahsi çıkarları için mücadele etmişlerdir. Türklere bağl1lı̆̆ından şüphesi olmayan geniş halk kesiminin ise dönemin şartları gereği fazla seçeneği bulunmuyordu. Şüphesiz İstanbul'da İttihat ve Terakki uygulamalarından bazıları aşiret reisleri ve yakınlarının isyana teşvik edilmesinde kullanılmıştır.

Nablus Savaşında uçakların tesiri çok açık olarak görülmekteydi (Tulga, 1980, s. 27). Nablus Savaşları savaşın son yıllarında Osmanlı ordusunun karşılaştı̆ı̆ sonucu itibariyle yıkımı çok 
olan bir muharebe olmuştur. Bu muharebelerde Osmanlı zayiatı çok kısa sürede 100. 000 kişiyi bulmuştur (Erickson, 2009, s. 197). Bu sayıdan 30. 000 civarında Mehmetçik şehit olmuştur. Şehit olan askerlerin büyük çoğunluğu ise uçakların ateşi ile gerçekleşmiştir. Filistin cephesinde uçakların taarruzuna yönelik olarak yaşanan trajedi birçok çalışmada yer almıştır. Bunlardan biri de harp mecmuasında geçen;"Havadan gelen tayyare taarruzlarını da hesaba katınca Türk ordusunun vaziyeti pek kolay anlaşılır. Havran mıntıkasında düştüğü bu sıkı çemberden bir ferdinin bile çıkamayacağı zan ve tahmin olunur. En doğru tabirle Türk ordusunu burada dört tarafindan avcılar ve en mükemmel vasitalarla ihata edilmiş bir yaralı aslana benzetmek en doğru bir tavsif olur. (Güralp, 1941, s. 41)" olarak tanımlanmıştır.

Osmanlı Devleti'nin I. Dünya Savaşı'nı kaybetmesinde uçakların ne kadar etkili olduğunu göstermesi bakımından, bir İngiliz pilotun anıları oldukça dikkat çekicidir. İngiliz pilotun 22 Eylül 1918 tarihli günlüğünde, "Bomba, tüfek ve ölüm yağmuru. Yüzlerce Türk, oldukları yerde durarak sadece ölümü beklemekten başka çare bulamıyorlardı. Bu adamlar gerçekten sinirli şeyler. Az sonra kendilerini öldüreceğimden dolayı yüreğim sizlıyor." (Keyüsk, 1952, s. 449; Sarp, 1986, s.95) ifadesi yer almaktadır. Tabii cephede ölümlerle Türklere yönelik mezalim bitmemiştir. Esir edilen Türklerin Mısır'da asitli havuzlarda gözlerini kaybetmeleri de önemli bir dram olmuştur. Hatta o kişilerin torunlarında tesirinin günümüze kadar görme bozuklukları olarak sürdüğü (Yel, 2014, Semp.) iddiaları da incelenmesi gereken bir mevzuudur.

Birinci Dünya Savaşı, İstiklal Savaşı Cephelerinde savaşan, 2. Dünya Savaşı'nda yine silahaltına alınan ve Üsteğmen rütbesi ile tezkere alan Filistin Cephesi gazilerinden Nazmi Koçoğlu, anılarında "Bizi en çok rahatsız eden İngiliz uçaklarıydı. ...Son olarak Mustafa Kemal Atatürk'ün dediği gibi “İstikbal göklerdedir” sözünün doğruluğuna ben Filistin Cephesi'nde bulunurken tanık olmuş ve içtenlikle inanmıştım.” (N. Koçoğlu, 2007, s. 3 - 6). şeklinde anlatmıştır. İngiliz Ordu Raporu, İngiliz savaş pilotu ve Türk gazisi farklı kelimeler ile aynı şeyi söylemektedir.

$\mathrm{Bu}$ dönemde Türkler cephede güçlü İngiliz hava üstünlüğü nedeniyle çok sınırlı hava güçlerini etkin kullanamamışlardır. 19 Eylül - 26 Ekim 1918'de yapılan son çarpışmalarda İngilizler, 260 top ele geçirmiş, 75. 000 Türk askerini esir almıştır. Türklerin aldığı esir 5. 000 olup bu sürede düşman kıtaatlar 350 ve süvariler 550 millik bir alanda ilerlemişlerdir. Savaş süresince kaybedilen Türk askeri sayısı yaklaşık bir milyon beş yüz bin insandır. Sivil halk ile bu rakam üç milyona yaklaşmaktadır. Oysa savaşın ilk yıllarında Osmanlı İmparatorluğu'nun kurtuluşunun bu savaş 
olduğuna toplum inandırılmıştır. Yenilgiler ve vatanın önemli parçalarının elden çıkması, üreten kesimin cephelerde kalması ve halkın omzuna yüklenen ağır vergi yükleri Osmanlı toplumunun psikolojisini derinden sarsmıştır (Talat Paşa - Hzrly. Kabacalı - 2011, s. 31 - 33). İşte Mustafa Kemal Atatürk'ün Nutuk'un ilk sayfasında yer verdiği toplumun yapısı ve ordunun durumu bu hâli en yalın hâli ile açıklayan oldukça başarılı bir betimlemedir (Atatürk, 1927, s. 1).

\section{1. Sonuç}

İngilizler tarih boyu uyguladıkları basit ama etkili bir yöntemi Filistin Cephesi’nde de tatbik ettiler. Burada, kuvvet ve gayretin konsantrasyonu yerine kuvvetlerin farklı yerlere dağıtılarak Türklerin birliklerinin de dağıtılmasını sağlamak, Türklerin yıpranmasını bekleyerek sonuca gitmek şeklinde bir yöntem tatbik edilmiştir (Tulga, 1980, s. 14). Türkler birçok farklı cepheye kuvvetlerini dağıtmış ve savaşın ikinci yılından itibaren hayatiyeti artan Filistin Cephesi sakin bırakılmıştır. Filistin Cephesi'nin çöküşünde uçakların etkisinin ne olduğu hususu aradan geçen bir asra yakın bir zaman dilimine rağmen detaylı olarak tartışılmamıştır ve sonuçlarından ders çıkarılmış değildir. Busbecq anılarında süvarilere verilen tüfeklerin, süvarinin elini kurum içinde bırakması, üniformasını kirletmesi, sarkan hantal barut kutularının alay konusu olması gibi nedenlerle rahatsızlığa neden olduğu ve oldukça temiz giyinen Osmanlı askerlerinin üzerinde bıraktığı lekeler sebebiyle istenmediğini yazar. Süvariler Rüstem Paşa'ya şikâyet ederek ok ve yaylarını tekrar isterler ve istekleri kabul edilir (Busbecq, 2005, s. 134). Belki de süvariler ok ve yayı ateşli silahtan daha seri kullanabilmekteydi. Ancak dünyadaki dönüşümün zamanında kavranamaması sonucu Batılı güçler ile arada oluşan teknolojik farklılık, dönüşü mümkün olmayan bir sürece girmiştir. Tarihi bütünlük açısından bakılırsa küçük aralar zamanla açılmış bir süre sonra yüzlerce uçakla gelen bir ordu karşısında Osmanlı ordusu mağlup olmuştur. Belki de burada dört yüzyılın farkını 1918 yılına dayandırmak farklı bir düşünce olarak değerlendirilse bile tarihe bütüncül olarak bakıldığında Filistin Cephesi’nde yaşanan çöküşün temelleri oldukça eski tarihlere dayanmaktadır.

Filistin Cephesi, Osmanlı İmparatorluğu açısından önemli ve hüzün dolu bir cephedir. $\mathrm{Bu}$ cephe ile ilgili tarihten uluslararası ilişkiler, askerî strateji, sosyoloji, toplum bilimi, iktisadi sahada ve daha birçok farklı disiplin ile bilim sahasında çıkarılacak ağır dersler bulunmaktadır. Zira bu cephe aynı zamanda bir imparatorluğun tasfiyesinin sonlandırılmasına yönelik son düğümlerden biri olmuştur. Türkler bu cepheden çekilirken Arap dünyası da huzurunu ve barış şartlarını en az yüz yıl kaybetmiştir. Sonrasını ise zaman gösterecektir. İlber Ortaylı'ya göre Genel Savaşın meydana getirdiği en büyük değişiklik imparatorluğun yıkılması ve bunun 
sonucu olarak Ortadoğu'da günümüzde yaşananlardır. Osmanlı yıkılmasaydı Ortadoğu'da bugünkü olaylar olmazd.

Filistin Cephesi Türk milletinin muharipliğinin ve dayanaklılığının imtihanı olmuştur. 1917 yılında İstanbul Amerikan ordu ataşesi Pentagon'a gönderdiği mesajında; “Filistin Cephesindeki Birinci Hat birlikleri yalnızca Türklerden oluşuyor....Onlar atılganlık ve zekaya dayanan girişimcilik konusundaki eksikliklerini olağanüstü dayanma güçleri ve hị̧ yakınmadan itaat etmeleri ile telafi eden, dayanıklı ve bütünüyle güvenilir bir asker topluluğu (Erickson, 2009, s. 168)" olarak tanımlamaktadır. Yine birçok farklı eserde bu durum açık olarak ifade edilmiştir. Şüphesiz bu cephede Türk subayı büyük bir direnç göstermiş, fedakârlıkta ve gayrette Alman subaylara liderlik yapmakta bilinenin aksine oldukça büyük bir performans göstermiştir, (Uyar - Erickson, 2014, s. 544 - 547).

Filistin Cephesi, ümidini kaybeden bir neslin savaş meydanlarına yığılıp kaldığı ancak hiçbir askerî ve ahlaki değere haiz olmayan emperyal güçlerin kahredici güçlerini orantısız ve

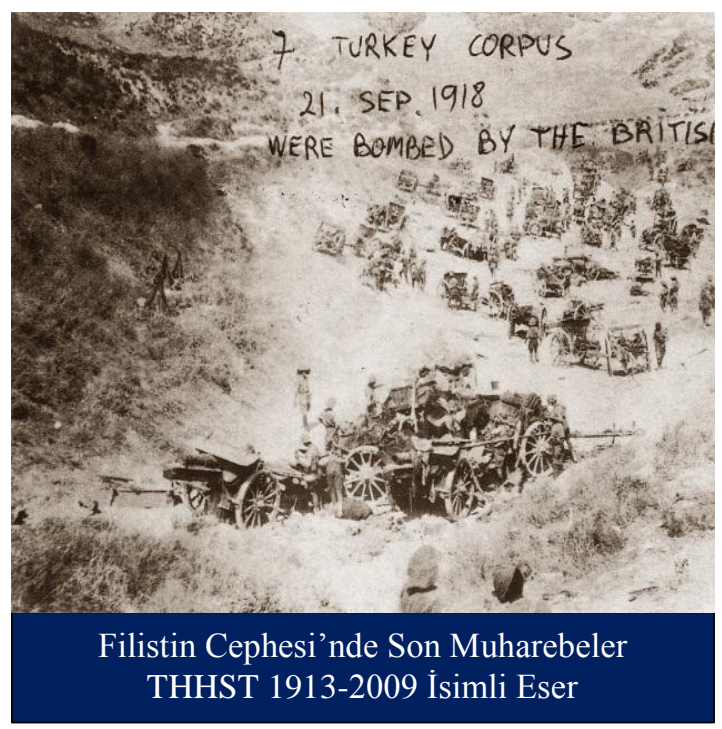
katliam ölçülerini de geçerek adeta soykırımı anımsatacak şekilde Türk milleti üzerinde tatbik ettiği bir alandır.

Filistin Cephesi ile ilgili söylenebilecek çok şeyler vardır. Belki de günümüzü de ilgilendiren boyutu ile bu cephe boş ümitlerle galeyana getirilerek kendi devletine karşı savaşa giren bir grubun bir milleti daha büyük sıkıntılara sevk etmesinin hikâyesidir. Başka bir ifade ile Filistin Cephesi mağlubiyeti; birkaç kişinin hayallerini gerçekleştirmek için ayartılarak Arap coğrafyasının bölünmesinin, enerji kaynaklarının yüz yıldır sömürülmesinin ve bölgede bulunan milletlerin birbirine düşürülerek burada asırlardır devam eden birlik ve dirliğin yerini her gün yüzlerce insanın akan kanının aldığı talihsiz bir asrın hikâyesidir.

Osmanlı İmparatorluğu uzun asırlar içerisinde bir Türk İmparatorluğu olarak varlığını sürdürmüştür. Ne var ki, son asırlarda Batı ile istemli olarak ilişkilerini geliştirmek istemesine rağmen Batı Avrupalı ülkeler tarafından aynı şekilde cevap verilmemiştir. Tecrit edilen büyük devlet kendi dinamiklerini de yenilemek zorunda kalmıştır. 1941 Yılında Harp Tarihi 
mecmuasında yer alan aşağıdaki ifade oldukça anlamlıdır. Güçlü olunan dönemlerde herkes daha fazla Türk'ken, zayıf zamanlarda ise hemen birçok kişi üç (3) nesil öncesinde başka millete mensup olduklarını söylemeye başlamaları elân kulaklardaki yerini ve hikâyelerini bilmektedir. Filistin Cephesi, milletin enerjisinin tükendiği bir dönemde yaşanan bir hikâyenin hazin sonucu olmuştur. Ancak başka bir gerçek ise Türklerin, Türkistan'dan Anadolu'ya yönelen büyük yürüyüşte karşılaştıkları güçlükler, kıyımlar, felaket yılları ve neredeyse bir milletin sonunun geldiğine şahit olunan hüzün yıllarıdır. Türkler tarihin en acı yıllarını bu süreçte yaşamış olmasına rağmen, takip eden dönemlerde Selçuklu ve Osmanlı İmparatorlukları gibi küresel güçlerle yeniden tarihte görülmüşlerdir.

\section{Kaynaklar}

Altın, Ş. (2014). Teşkilat-ı Mahsusa bir gizli teşkilatın öyküsü. İstanbul: İlgi Kültür Yayınları Atatürk Kitaplığ , Albümler, İBȘB, Taksim, İstanbul.

Arslan, E. (2015). Bir ABD istihbarat ajanının gözünden suriye'deki 4'üncü ordu ve gazze muharebeleri. Uluslararasl Sempozyum 1914'ten 2014'e 100'üncü Yllında Birinci Dünya Savaşı'nı Anlamak 20-21 Kasım 2014, İstanbul: Harp Akademileri Basımevi

Artuner, B. (2005). Kayıp topraklar. İstanbul: Truva Yayınları

Atatürk, M. K. (1927). Nutuk. Ankara: Eski Türkçe Birinci Basım.

Başbakanlık Osmanlı Arşivi (BOA), Y.MTV,285/162

Baytok, T. (2007). Ingiliz belgeleriyle Sevr'den Lozan'a dünden bugüne değişen ne var?. İstanbul: Doğan Kitapevi

BOA, DHSYS,123-1235,10 Mart 1915 (Kabulü:11 Kasım 1914)

BOA, HR.SYS.,2333/3

BOA, İ_DUIT_00001_000028_002_001

BOA, ŞD,TNZ,2272/86

BOA, Y.A.Res, $5 / 58$

BOA,HR,SYS, $2160 / 3$

BOA,İ.MMS,123/5276;

BOA,Y.PRK.AZJ,30/37

BOA,Y.PRK.EŞA, 13/67

BOA,Y.PRK.TKM,41/5

BOA,Y.PRK.UM,23/66

Busbecq, O. G. (2005). (çev.: Derin TÜRKÖMER - ed. Emre YALÇIN). Türk mektupları Kanuni döneminde avrupalı bir elçinin gözlemleri (1555-1560). İstanbul: Türkiye İş Bankası Kültür Yayınları. 
Çavdar, T. (2004). Türkiye'nin demokrasi tarihi 1839 - 1950. 3.Bask1, Ankara: İmge Yay.

Çavuş, R. (2006). Hain kim bir isyanın perde arkası. İzmir: Yitik Hazine Yay.

Çayc1, A. (1995). Büyük Sahra'da Türk - Fransız rekabeti (1858 - 1911). Ankara: TTK

Erdoğan, M. (1986). Hava Gücü ve Savaş. Ankara: Gnkur. Bsm.

Erickson, E. J. (2009). (çev.: Kerinm BAĞRIAÇIK). I. Dünya Savaşı'nda Osmanlı ordusu Çanakkale-Kut'ül Amare ve Filistin Cephesi. İstanbul: Türkiye İş Bankası Kültür Yayınları.

Gnkur. ATASE Arşivi,BDH-1425-167A-001-03a

Gnkur. ATASE, BDH,1425-167A-001-01a

Gnkur. ATASE, BDH-1425-167A-001a

Göymen İ. Birinci Dünya Harbi IX Cilt Türk Hava Harekâtı. Ankara: Gnkur. Bsm.

Guhr, H. (2007). Anadolu'dan Filistin'e Türklerle omuz omuza. İstanbul: Türkiye İş Bankası Kültür Yayınları.

Güralp, Ş. (1969). 1918 Senesinde Türk Ordusunun ve Suriye'den Çekilişinde 3. Süvari Tümeninin Hareketleri. (1941). Askeri Местиа, İstanbul: İstanbul Askeri Matbas1, 120. Sayının Lahikası.

Ian, W. (2014). I. Dünya Savaşı. İstanbul: Türkiye İş Bankası Kültür Yayınları.

Kabacalı, A. (2010). (Hazırlayan), Hatıralar Cemal Paşa. 5.Baskı. İstanbul: Türkiye İş Bankası Kültür Yayınları.

Kansu, Y. ve Şensöz, S. Ö. (1971). Yılmaz. Havacılık Tarihinde Türkler, Ankara: Hava Kuvvetleri Basımevi.

Keser, U. (2013). Birinci Dünya Savaşı sürecinde Akdeniz ve Kıbrıs bölgesinde Türk havacılık faaliyeti. Türk Hava Kuvvetlerinin 100'üncü Yılı Uluslararası Tarih Sempozyumu 8 - 10 Şubat 2011, Ankara.

Keyüsk, M. (1950). Türk Havacılık tarihi (1912 - 1914), birinci kitap. Eskişehir: Uçuş Okulları Basimevi

Keyüsk, M. (1951). Türk Havacılık tarihi (1914 - 1916), ikinci kitap birinci cilt. Eskişehir: Hava Basımevi.

Keyüsk, M. (1952). Türk Havacıllk tarihi (1917 - 1918), ikinci kitap ikinci cilt. Eskişehir: Hava Basımevi.

Kocatürk, Ö. (2011). Osmanl - İngiliz ilişkilerinin dönüm noktası (1911 - 1914). İstanbul: Boğaziçi Yayınları.

Miralay, E. Muzaffer. (2011). Büyük Harpte Mısır seferi çerçevesinde birinci kanal akını. Askeri Местиа, 33, 1 Mart 1934, İstanbul: Askeri Matbaas1.

Özbilen, E. B. (2011). (çev.)- Çekmece Özlem (ed.), Denizlerde yenilmediler cihan harbinde Alman harbiyeliler. İstanbul: Türkiye İş Bankası Kültür Yayınları

Özdemir, H. ve Subaşı, E. (2009). Osmanlı belgelerinde Filistin. İstanbul: Seçil Ofset. 
$594^{\text {* TAED }} 55$

Osman YALÇIN

Palmer, A. (1992). (çev. Belkıs Çorakçı Dişbudak). Osmanlı Imparatorluğu son ü̧̧ yüz yıl bir çöküşün yeni tarihi. İstanbul: Yeni Yüzyıl Tarih Dizisi.

Paşa, M. T. (Hazırlayan: Alpay KABACALI). Talat Paşa'nın anıları. 6. Baskı, İstanbul: Türkiye İş Baknası Kültür Yayınları.

Sarısır, S. (1998). Atatürk dönemi millî hava harp sanayii içinde Kayseri Tayyare Fabrikasının yeri. Erciyes Üniversitesi Sos.Blm.Enst., Basılmamış Yüksek Lisans Tezi, Kayseri.

Sözeri, E. N. (1961). Türk tayyareciliği. Hava Kuvvetleri Dergisi, 202.

Süslü, A. (1998). Misak-1 Millî, 1914 - 1920. Misak-ı Millî ve Türk Dış Politikasında Musul, Ankara: Atatürk Araştırma Merkezi.

Taşkıran, C. (2011). Ana ben ölmedim. 4. Baskı. Ankara: Türkiye İş Bankası Kültür Yayınları.

Tekin, Y. (2009). II. Abdülhamit'ten Cumhuriyet'e miras bir ulus devlet yaratma mücadelesi. İstanbul: Gökkubbe Yayınları.

Tokgöz, E. (2001). Türkiye'nin iktisadi gelişme tarihi (1914 - 2001). Ankara: İmaj Yayınevi.

Tolon, A. H. (2004). Birinci Dünya Savaşı sonrasında taksim anlaşmalarl ve Sevr'e giden yol. Ankara: AAM

Tulga R. H. (1980). Askeri strateji prensipleri ve Atatürk. Uluslararası Atatürk Konferansl, İstanbul: Boğaziçi Üniversitesi.

Tunçay M. ve Akşin, S. (1990). Çağdaş Türkiye 1908 - 1980. İstanbul: Cem Yayınevi.

Türkmen, Z. (2015). Birinci Dünya Harbi’nde Irak Cephesinde Türk - İngiliz mücadelesi. Uluslararası Sempozyum 1914'ten 2014'e 100'üncü Yılında Birinci Dünya Savaşı'nı Anlamak 20-21 Kasım 2014, İstanbul: Harp Akademileri Basımevi.

Uyar, M. ve J. Erickson, E. (2014). Osmanlı askerî tarihi. İstanbul: Türkiye İşbankası Kültür Yayınlar1.

von Kressenstein, F. F. K. (2007). (çev.:Tahir BALABAN). Son Haçlı Seferi kuma gömülen imparatorluk. İstanbul: Yeditepe Yayınları.

Yalçın, O. (2004). Türk Hava Kuvvetleri teşkilatlanma tarihi (Cumhuriyet Dönemi). G. Ü. Sos. Blm. Enst., Basılmamış Yüksek Lisans Tezi, Ankara.

Yalçın, O. (2008). Türk hava harp sanayii tarihi. Basılmış Doktora Tezi, G. Ü. Sos. Bil. Enst, Ankara.

Yalçın, O. (2009). Türk hava harp sanayii tarihi 1913 - 2009. Ankara: Hv. Bsm. ve Neş.

Yalçın, O. (2010). Türkiye Cumhuriyeti Devleti'nin uçak fabrikası kurma mücadelesinde ilk girişim:tayyare ve motor Türk anonim şirketi (TOMTAŞ) ve Kayseri uçak fabrikası. Atatürk Araştırma Merkezi Dergisi, 78, Cilt XXVI, Ankara, Kasım 2010.

Yalçın, O. (2013). Amerikan toplumunun oluşumu ve güç merkezi olma stratejisi. Uşak Sosyal Bilimler Dergisi, 3 / 3.

Yalçın, O. (2013). Türk hava harp sanayii tarihi. İstanbul: Türkiye İş Bankası ve Kültür Yayınlar1.

Yalçın, O. (2015). Savaş uçakları ve balonlar. Birinci Dünya Savaşı'nda Osmanlı Devleti, İstanbul: Kitapevi. 
Yel, S. (2014). Kafkas Cephesi. 100’üncü Yılında Birinci Dünya Savaşı Sempozyumu 24 Ekim 2014, Gnkur. ATASE D.Bşk.lığı, Hava Harp Okulu Şehit Muzaffer Erdönmez Sinema Salonu, İstanbul.

Yengin, S. (2007). haz. Tetik, Ahmet - Seven, Ayşe. Drama'dan Sina - Filistin'e savaş günlüğü (1917 - 1918), Ankara: Gnkur ATASE Yay.

Yılmaz, M. ve K1lınçkaya D. (2008). Atatürk ve Türkiye Cumhuriyeti tarihi, 9. Bask1, Ankara: Siyasal Kitapevi.

Y1lmaz, V. (2003). Cumhuriyet tarihi I, İstanbul: Harp Akademileri Yay.

Yücel, C. (1963). Türk Havacılığının Kısa Tarihçesi. Hava Dergisi, 211, Eylül 1963, Ankara.

\section{Süreli Yayınlar}

Filistin cephesi gazilerinden Nazmi Koçoğlu ile yapılan röportaj. TRT, Tarihçe Ş.Arşivi Klasör Nu.:85, 2007.

Harp Tarihi Mecmuları, (2012), Atatürk Kitaplığı, İstanbul.

İkdam, 3 Mayıs 1915.

İkdam, 12 May1s 1915.

Tasfir-i Efkar, 13 Nisan 1914. 